\title{
Sedimentary factories and ecosystem change across the Permian-Triassic Critical Interval (P-TrCl): insights from the Xiakou area (South China)
}

\author{
Yu Pei ${ }^{1}$ (D) Jan-Peter Duda ${ }^{1,2}$. Joachim Reitner ${ }^{1,2}$
}

Received: 18 April 2020 / Accepted: 12 September 2020 / Published online: 5 November 2020

(c) The Author(s) 2020

\begin{abstract}
The Permian-Triassic mass extinction included a potentially catastrophic decline of biodiversity, but ecosystem change across this event remains poorly characterized. Here we reconstruct sedimentary factories and ecosystem change across the Permian-Triassic Critical Interval (P-TrCI) in the Xiakou area (South China). Six microfacies (MF) were classified. The succession begins with a eukaryote-controlled carbonate factory (MF-1) that passes upward into an organomineralizationdominated carbonate factory (MF-2-3). Organic-rich marls atop these units reflect carbonate factory collapse (MF-4). Organomineralization-driven carbonate formation restarts prior to the Permian-Triassic boundary (MF-5) and subsequently develops into a mixed carbonate factory where organomineralization and biomineralization are almost equally important (MF-6). MF-1 reflects oxygenated shallow water environments. In contrast, MF-2-6 were all deposited in somewhat deeper environments, some of which episodically exhibited elevated salinities, oxygen depletion, and, possibly, euxinic conditions. Our results demonstrate that distinct changes in carbonate production styles, biodiversity, and environmental conditions are not synchronous at Xiakou. Furthermore, the Xiakou record is strikingly different to that of other localities, even from the same area (e.g., the Global Stratotype Section and Point section at Meishan). Together, these findings highlight the enormous complexity of the P-TrCI and calls simplified views of the Permian-Triassic mass extinction into question.
\end{abstract}

Keywords Permian-Triassic mass extinction · Biomineralization · Organomineralization · Carbonate factory $\cdot$ Environmental change $\cdot$ Microfacies $\cdot$ Geobiology

\section{Introduction}

The Permian-Triassic (P-Tr) mass extinction is characterized by a potentially catastrophic decline of biodiversity in marine and terrestrial ecosystems (Benton and Twitchett 2003; Wignall 2007; Chen and Benton 2012; Payne and Clapham 2012). For the marine realm, this view is mainly based on rarefaction curves that indicate as many as $96 \%$ of all species disappeared (Raup 1979) and findings from fossil databases that suggest $52 \%$ of all families went extinct

Handling Editor: Mike Reich.

Yu Pei

yu.pei@geo.uni-goettingen.de

1 Department of Geobiology, Geoscience Center, GeorgAugust-Universität Göttingen, Göttingen, Germany

2 'Origin of Life' Group, Göttingen Academy of Sciences and Humanities, Göttingen, Germany
(Sepkoski et al. 1981; Raup and Sepkoski 1982). Later studies based on paleontological databases supported this view (Fan et al. 2020), proposing that $78 \%$ of all marine genera were wiped out at the end of the Permian (Alroy et al. 2008). Others argue that these extinction rates might be overestimated (cf. Erwin 1994; Stanley 2016).

A prolonged period of recovery followed the $\mathrm{P}-\mathrm{Tr}$ mass extinction (Lehrmann et al. 2006; Chen and Benton 2012). Strong shifts in the carbon stable isotopic composition of sedimentary carbonates $\left(\delta^{13} \mathrm{C}_{\text {carb }}\right.$ of ca. $-3-8 \%$ ) support the notion of long-lasting ecological disturbances in its aftermath (Payne et al. 2004). Marine sulfate concentrations were significantly lower in the Early Triassic as compared to today ( $\leq 6 \mathrm{mM}$, i.e., $<20 \%$ of modern-day seawater), as indicated by profound variations in carbonate associated sulfate and sulfate sulfur isotopes $\left(\delta^{34} \mathrm{~S}_{\text {cas }}\right.$ of ca. $9-44 \%$ and $\delta^{34} \mathrm{~S}_{\text {sulfate }}$ of ca. 10-32\%o, respectively) (Luo et al. 2010; Song et al. 2014; Bernasconi et al. 2017). Organisms in Early Triassic oceans were additionally stressed by high levels of toxic 
ammonium and a decline in bioavailable nitrogen, as indicated by analysis of bulk rock nitrogen isotopes $\left(\delta^{15} \mathrm{~N}_{\text {bulk }}\right.$ of ca. 1-3\%o) (Grasby et al. 2019; Sun et al. 2019).

An important characteristic of the $\mathrm{P}-\mathrm{Tr}$ mass extinction is the widespread occurrence of unusual sedimentary features in the event's aftermath (Woods 2014; Chen et al. 2019). Examples include vermicular fabrics in limestones (Zhao et al. 2008) as well as fan- and calyx-shaped calcium carbonate precipitates (Woods et al. 1999; Woods 2014; Heindel et al. 2015). A further striking feature is the abundance of microbialites that developed on carbonate platforms in lowlatitude regions of the Paleo-Tethys (Lehrmann 1999; Kershaw et al. 1999, 2012; Ezaki et al. 2003, 2008; Wang et al. 2005, 2016, 2019; Liu et al. 2007; Wu et al. 2007, 2017; Yang et al. 2011, 2019; Forel 2013; Lehrmann et al. 2015; Adachi et al. 2017; Fang et al. 2017; Tang et al. 2017; Chen et al. 2019; Foster et al. 2019; Pei et al. 2019). The unusual sedimentary features may reflect the persistence of unconventional environmental conditions associated with the endPermian crisis (Bottjer et al. 2008; Chen and Benton 2012), while the widespread proliferation of microbial mats likely resulted from a suppressed ecological competition during this time (Foster et al. 2020).

The causes and triggers of the P-Tr mass extinction are still debated. One of Earth's largest continental flood basalt provinces - the Siberian Traps-formed during this time and may have led to the mass extinction (Burgess and Bowring 2015; Burgess et al. 2017), as for instance indicated by a marked mercury anomaly (Wang et al. 2018). Volatiles such as halogens (Broadley et al. 2018), $\mathrm{CO}_{2}$, and $\mathrm{SO}_{2}$ (Wignall 2007) released from the massive, rapid outpouring of lavas could have affected Earth's climate, raising seawater temperatures (Joachimski et al. 2012; Sun et al. 2012) and spreading anoxic conditions throughout Late Permian oceans (Grice et al. 2005; Brennecka et al. 2011; Elrick et al. 2017; Huang et al. 2017; Penn et al. 2018; Zhang et al. 2018). Other potential causes of the $\mathrm{P}-\mathrm{Tr}$ mass extinction that were possibly, but not necessarily, related to volcanism include ocean acidification (Payne et al. 2010; Hinojosa et al. 2012; Clarkson et al. 2015) and hypercapnia (Knoll et al. 2007). It is likely that a combination of forces and processes interacted in complex ways to cause the mass extinction, and also make it difficult to directly link those causes to environmental consequences during this period.

This apocalyptic scenario might be oversimplified because fossil records covering the $\mathrm{P}-\mathrm{Tr}$ extinction event are largely limited to marine shelf environments of Pangaea, reflecting conditions in a narrow belt and not necessarily those of remote parts of oceans. Furthermore, most of today's organism families are unlikely to be preserved as fossils (Plotnick et al. 2016). By analogy, paleontological databases only comprise a fraction of groups that existed during $\mathrm{P}-\mathrm{Tr}$ times. At the same time, fossilized groups are variably and inconsistently classified, making quantitative comparisons complicated. The occurrence of various Lazarus taxa (Jablonski 1986) in the Triassic (Erwin 1994; Wignall and Benton 1999) suggests the presence of unrecorded habitable refugia and of taphonomic biases, emphasizing the significance of such problems (Fraiser et al. 2011). A sound understanding of the complex interplay between biotic and abiotic processes through crucial junctures in Earth history requires more than studies of fossil databases (cf. Erwin 1994; Stanley 2016).

Rock-based approaches to studies of past ecosystems require well-preserved records. South China is known for numerous exquisitely preserved sedimentary successions that cover the Permian-Triassic critical transition, referred to as Permian-Triassic Critical Interval (P-TrCI) in the following. One well-known example is the Meishan Sectionthe Global Stratotype Section and Point (GSSP) for the P-Tr boundary (Yin et al. 2001). In this section, the P-Tr extinction horizon is positioned between Beds $24 \mathrm{e}-5$ and $24 \mathrm{e}-6$ (Chen et al. 2015), and it may be possible to directly correlate those beds with equivalent layers around the globe. A problem in making such correlations is that paleontological and $\delta^{13} \mathrm{C}_{\text {carb }}$ evidence from South China reveals a complex scenario of the P-TrCI because of the presence of one (Jin et al. 2000; Shen et al. 2019), two (Xie et al. 2007; Yin et al. 2012; Song et al. 2013; Chen et al. 2015), or even three extinction pulses (Yang et al. 1991). Inconsistencies between the manifestation of extinction events globally points out the need for detailed facies studies in order to better understand the variety of ecological changes during the $\mathrm{P}-\mathrm{TrCI}$.

Our study aims to unravel the complex interplay between biotic and abiotic processes through the $\mathrm{P}-\mathrm{TrCI}-$ one of the most critical evolutionary junctures in Earth's history-by studying facies in the Xiakou area (Hubei Province, South China) (Fig. 1). We use a rock-based approach that involves integration of sedimentary, paleontological, and biogeochemical evidence. Particular emphasis is placed on carbonate factory development during the $\mathrm{P}-\mathrm{TrCI}$ as a measure of biological activity. This strategy allows for robust reconstruction of environmental conditions and ecosystem dynamics in this critical interval.

\section{Geological background}

The Xiakou section (GPS: N31 ${ }^{\circ} 06.874^{\prime}, \mathrm{E} 110^{\circ} 48.209^{\prime}$ ) is located between the town of Xiakou and the village of Jianyangping in western Hubei, South China (Fig. 1a). The section is well exposed and easily accessible in a gorge cut by the Gaolan River.

During P-Tr times, the Xiakou area was located in a shelf basin in the northernmost part of South China, adjacent to the Yangtze Platform (Feng et al. 1997) (Fig. 1b). 
Fig. 1 Study area. a Location of the Xiakou section, between the town of Xiakou and the village of Jianyangping (western Hubei Province, China). b Paleogeographical map of South China during the Changhsingian Stage (modified from Feng et al. 1997). The Xiakou area was situated in a shelf basin in the northernmost part of South China, adjacent to the Yangtze Platform
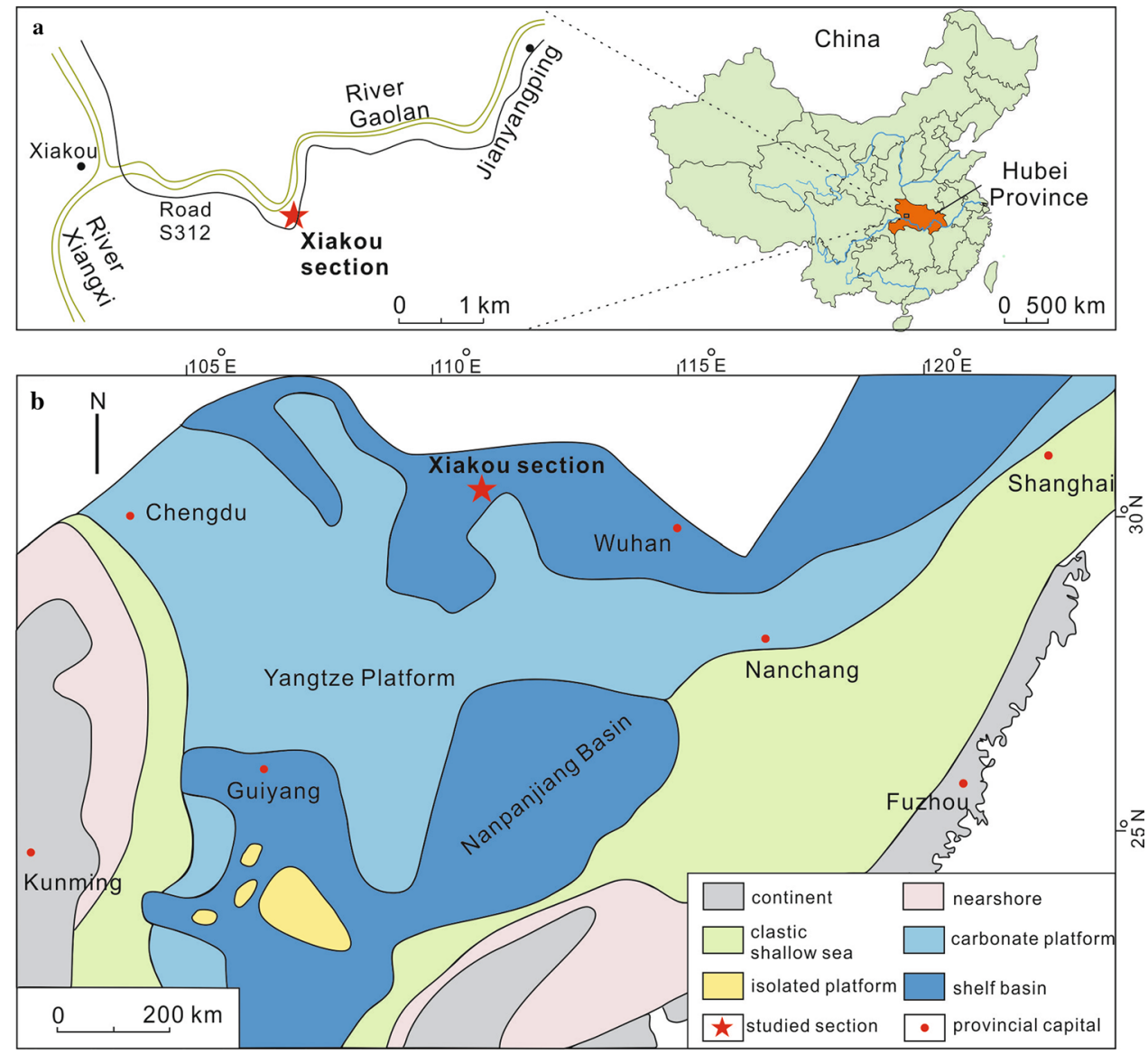

The Xiakou section comprises (from base to top) the Changxing and Dalong Formations (both Changhsingian) as well as the Daye Formation (uppermost Changsingian to Induan) (Fig. 2). The P-Tr boundary is placed within the lowermost Daye Formation at the base of Bed $\mathrm{T}_{1}$ (red line), as indicated by the first appearance of conodont Hindeodus parvus (Zhao et al. 2013).

\section{Materials and methods}

\section{Fieldwork and petrography}

Fieldwork was conducted in 2017 and 2019. Both campaigns included detailed observations and documentations of the Xiakou section and surrounding areas (Fig. 2). A total of 23 beds were sampled for subsequent petrographic and biogeochemical analyses (see below).

Thin sections (ca. three per sample) were analyzed using a Zeiss SteREO Discovery.V12 stereomicroscope and a Zeiss AXIO Imager.Z1 microscope coupled to an AxioCamMRc camera (transmitted and reflected light, respectively).

\section{Analytical imaging techniques}

For epifluorescence microscopy, a Zeiss AXIO Imager. $\mathrm{Z} 1$ microscope equipped with a high-pressure mercury arc lamp (HBO 50, Zeiss; controlled by an EBX 75 ISOLATED electronic transformer) and a $10 \mathrm{AF} 488$ filter (excitation wavelength $=$ BP $450-490 \mathrm{~nm}$, emission wavelength $=\mathrm{BP}$ $515-565 \mathrm{~nm}$ ) was used.

For cathodoluminescence (CL) microscopy, a Cambridge Instruments Citl CCL $8200 \mathrm{Mk} 3 \mathrm{~A}$ cold-cathode system was linked to a Zeiss Axiolab microscope (operating voltage of ca. $15 \mathrm{kV}$; electric current of ca. 250-300 $\mu \mathrm{A}$ ) and a Zeiss AxioCam 703 camera.

For field emission scanning electron microscopy (FeSEM), a Carl Zeiss LEO 1530 Gemini system was used. EDX spectra and elemental maps were acquired with an Oxford Instruments INCA $\mathrm{x}$-act energy dispersive X-ray spectrometry (EDX) detector coupled to the Fe-SEM system.

Raman spectra were collected using a WITec alpha300R fiber-coupled ultra-high throughput spectrometer at the Geosciences Center, University of Göttingen. Before analysis, the system was calibrated using an integrated light source. The experimental setup included a $405 \mathrm{~nm}$ laser, $10 \mathrm{~mW}$ laser power, a $100 \times$ long working distance objective with a 
Fig. 2 The Xiakou section, showing stratigraphical, sedimentological, paleontological, and geochemical features across the P-TrCI. Note that sample $\mathrm{P}_{\mathrm{b} 1}$ is not displayed. C.m. $=$ Clarkina meishanensis, C.t. = Clarkina taylorae, H.p. $=$ Hindeodus parvus, I.s. $=$ Isarcicella staeschei

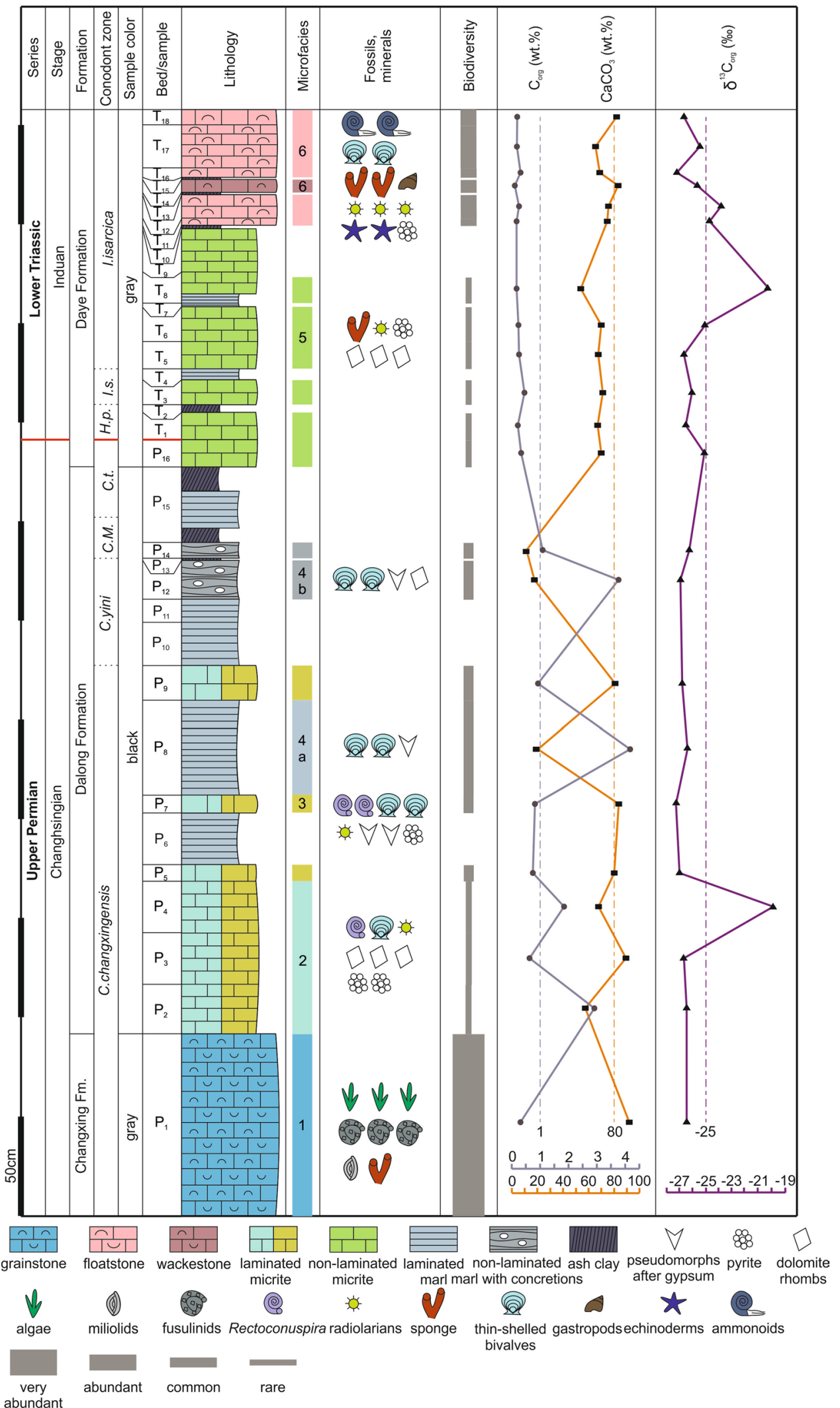


numerical aperture of 0.75 , and a $1200 \mathrm{~g} \mathrm{~mm}^{-1}$ grating. This setup had a spectral resolution of $2.6 \mathrm{~cm}^{-1}$. The spectrometer was centered at $1530 \mathrm{~cm}^{-1}$, covering a spectral range from 122 to $2759 \mathrm{~cm}^{-1}$. The $405 \mathrm{~nm}$ laser was chosen to reduce fluorescence effects. Each spectrum was collected by two accumulations, with an acquisition time of $60 \mathrm{~s}$. Raman spectra were processed with the WITec project software. The background was subtracted using a rounded shape and band positions were determined by fitting a Lorentz function.

\section{Bulk analyses}

Bulk analyses (total organic carbon, $\mathrm{C}_{\text {org }}$; total inorganic carbon, $\mathrm{C}_{\text {carb }}$ ) were executed using a Leco RC612 carbon analyzer and a Hekatech Euro EA elemental analyzer. $\mathrm{C}_{\text {carb }}$ values were used to calculate $\mathrm{CaCO}_{3}$ contents for all samples.

\section{Stable isotopes $\left(\delta^{13} C_{\text {carb, }} \delta^{18} O_{\text {carb, }} \delta^{13} C_{\text {org }}\right)$}

Carbon and oxygen stable isotopic compositions of carbonates were analyzed in the Isotope Geology Department at the Geoscience Center of the Georg-August-Universität Göttingen (Germany). Individual mineral phases were sampled with a high-precision drill, permitting the isolation of minute amounts of sample powder (ca. 100-600 $\mu \mathrm{g}$ ). The isotope measurements were performed at $70{ }^{\circ} \mathrm{C}$ using a Thermo Scientific Kiel IV carbonate device coupled to a Finnigan DeltaPlus gas isotope mass spectrometer. Carbon and oxygen stable isotope ratios of carbonate minerals are reported as delta values relative to Vienna Pee Dee Belemnite (VPDB) reference standard $\left(\delta^{13} \mathrm{C}_{\text {carb }}\right.$ and $\delta^{18} \mathrm{O}_{\text {carb }}$, respectively). Reproducibility was tested through the replicate analysis of standard NBS19 and was generally better than $0.1 \%$.

Carbon stable isotopic compositions of bulk organic matter were analyzed at the Center for Stable Isotope Research and Analysis (KOSI) at the Georg-August-Universität Göttingen (Germany). An elemental analyzer (NA-2500 CE-Instruments) coupled to an isotope ratio mass spectrometer (Finnigan MAT Delta plus) was used to determine carbon isotopic abundances. About $1 \mathrm{~g}$ of each sample was decalcified, washed, and neutralized, and ca. $0.2-15 \mathrm{mg}$ of the remaining material was analyzed. The carbon stable isotope ratios of bulk organic matter are reported as delta values relative to VPDB reference standard $\left(\delta^{13} \mathrm{C}_{\mathrm{org}}\right)$. For internal calibration an acetanilide standard was used $\left(\delta^{13} \mathrm{C}=-29.6 \%\right.$; $\left.\mathrm{SD}=0.1\right)$. The average $\delta^{13} \mathrm{C}_{\text {org }}$ value had a standard deviation of 0.3 .

\section{Results}

\section{Field observations}

The part of the Xiakou section we investigated is about $9 \mathrm{~m}$ thick (Fig. 2). It begins with ca. $4 \mathrm{~m}$ of the uppermost Changxing Formation at the base (Beds $\mathrm{P}_{\mathrm{b} 1}$, and $\mathrm{P}_{1}$ ), which is composed of gray, thick-bedded to massive grainstones that locally contain silicate nodules. The overlying Dalong Formation (Beds $\mathrm{P}_{2}-\mathrm{P}_{16}$ : Fig. $3 \mathrm{a}$ ) is ca. $3 \mathrm{~m}$ thick and mainly composed of black, thin- to medium-bedded micrites intercalated with black mudstones and greenishyellowish volcanic ash layers (particularly abundant in Bed $\mathrm{P}_{15}$ ). The Daye Formation (only ca. $2 \mathrm{~m}$ covered here, Beds $\mathrm{T}_{1}-\mathrm{T}_{18}$ : Fig. $3 \mathrm{a}, \mathrm{b}$ ) terminates the section and consists of gray, thin- to medium-bedded micrites, wackestones, and floatstones, locally intercalated with black shales and thin greenish-yellowish volcanic ash layers. Few beds seem to pinch out laterally $\left(\mathrm{T}_{5}, \mathrm{~T}_{6}\right.$ : Fig. $\left.3 \mathrm{~b}\right)$.

\section{Microfacies analysis}

Based on sedimentary and paleontological criteria, six distinct microfacies (MF) can be distinguished.

MF-1 Gray grainstone with dasyclad green algae and fusulinid foraminifers (Fig. 4a)

Samples: $\mathrm{P}_{\mathrm{b}}, \mathrm{P}_{1}$ (Changxing Formation).

Carbonate components (mainly fossils) typically range in size from 0.5 to $2 \mathrm{~mm}$. They are poorly rounded and moderately sorted. Few fossils are fragmented. The most abundant fossils are Dasycladaceae (e.g., Mizzia) and Fusulinidae. Other abundant constituents are Gymnocodiaceae and Miliolidae. In addition, demosponges, ostracods, echinoderms, bryozoans, brachiopods, and bivalves occur.

MF-2 Black laminated micrite with dolomite rhombs (Fig. 4b-d).

Samples: $\mathrm{P}_{2}-\mathrm{P}_{4}$ (Dalong Formation).

The MF contains abundant small $(5-25 \mu \mathrm{m})$ dolomite rhombs situated in a fine-grained calcite matrix. The rhombs exhibit a strong green fluorescence (especially in their outer rims) and CL zoning (Fig. 4b-d). In addition, there are rare occurrences of lenticular twinned calcite pseudomorphs (about $0.1 \mathrm{~mm}$ ) after gypsum.

Fossils include thin-shelled bivalves, small benthic foraminifera, and fish bones (Fig. 4b). Locally, globular silica tests of radiolarians replaced by carbonate are observed. 
Fig. 3 Field photos of the Xiakou section, showing the Dalong and Daye formations (beds $\mathrm{P}_{4}-\mathrm{P}_{15}$ and $\mathrm{P}_{16}-\mathrm{T}_{1}$, respectively). The $\mathrm{P}-\mathrm{Tr}$ boundary is situated between beds $P_{16}$ and $\mathrm{T}_{1}$ in the lowermost Daye Formation. Person (a) and hammer $(\mathbf{b})$ for scale
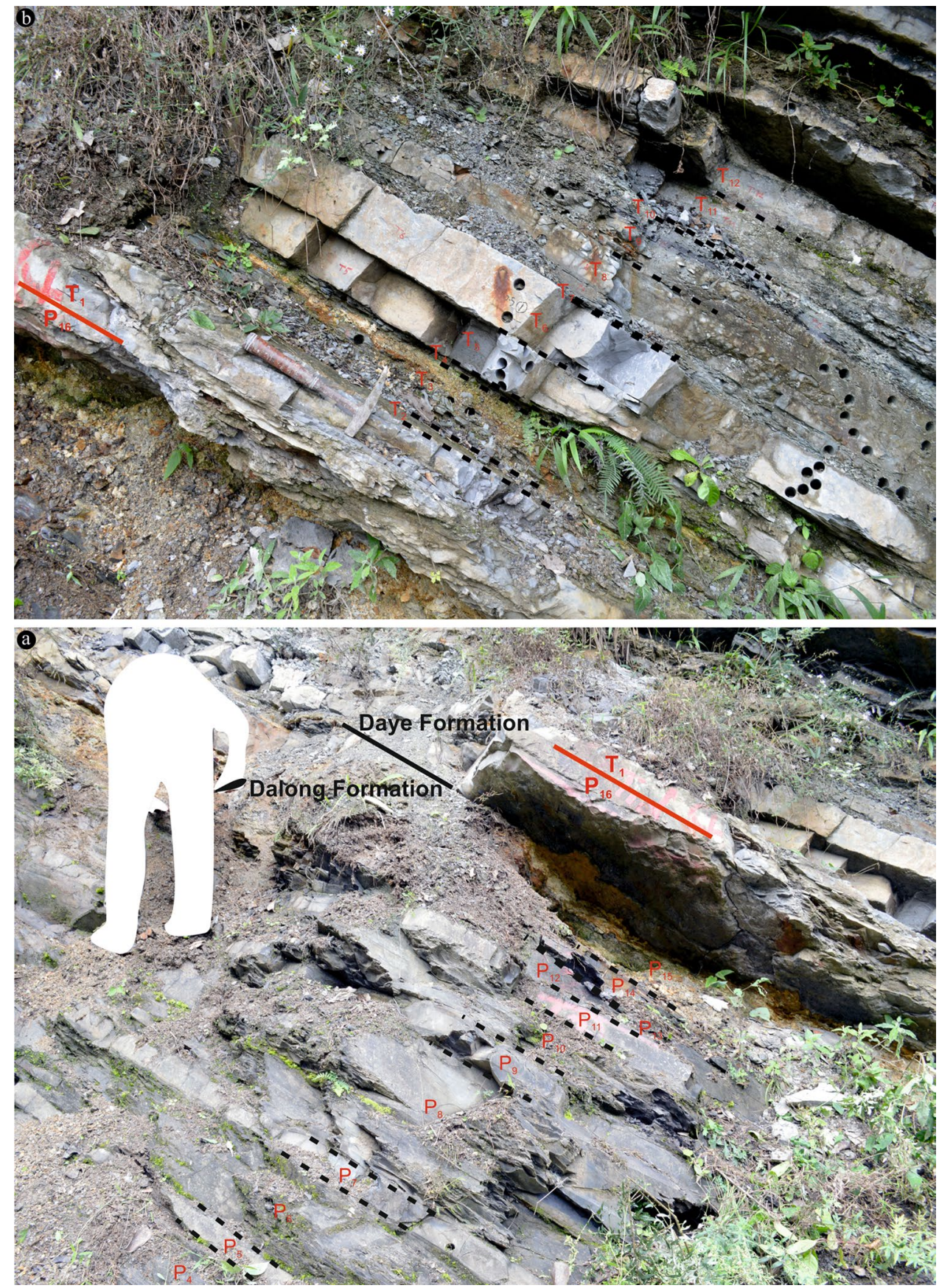

MF-3 Black laminated micrite with abundant calcite pseudomorphs after gypsum and Rectocornuspira foraminifers (Fig. 4e-h).

Samples: $\mathrm{P}_{5}, \mathrm{P}_{7}, \mathrm{P}_{9}$ (Dalong Formation).

This MF contains high abundances of calcite pseudomorphs after gypsum $(0.1-0.5 \mathrm{~mm}$; ca. $30 \%$ of total area in cross sections) (Fig. 4e). These components are lenticular and partly twinned and aggregated (Fig. 4e). In cross sections, about $64 \%$ of the pseudomorphs $(N=129)$ exhibit angles of $60^{\circ}-120^{\circ}$ between their long main axis and the sedimentary bedding plane (Fig. 5).
Some calcite-rich laminae contain abundant megalospheric and microspheric stages of the benthic foraminifer Rectocornuspira (Fig. 4f-h), which are characterized by large and small initial chambers, respectively (Goldstein 1999). The megalospheric A-forms exhibit mean diameters of ca. $153 \mu \mathrm{m}(N=38)$, while the microspheric B-forms are ca. $249 \mu \mathrm{m}$ in diameter on average $(N=75)$ (Fig. 6). Other fossils such as small benthic foraminifera, thin-shelled bivalves, and radiolarians were rarely observed. 
Fig. 4 Thin section images of microfacies (MF) 1-3. a MF-1: Gray grainstone with dasyclad green algae (Da) and fusulinid foraminifers. $\mathrm{Gy}=\mathrm{Gym}$ nocodiaceae. b-d MF-2: Black laminated micrite with dolomite rhombs (Rh). The dolomite rhombs (b) exhibit a strong green fluorescence (c; same thin section as b) and CL zoning (d). Fossils are rare in this MF and include fish remains (FR) (b-c). e-h MF-3: Black laminated micrite with abundant calcite pseudomorphs after gypsum and Rectocornuspira foraminifers. The calcite pseudomorphs after gypsum $(\mathrm{Gp})$ locally form aggregates (e). Notably, this MF contains abundant A- and B-forms of Rectocornuspira (A-f and B-f in $\mathbf{f}-\mathbf{h}$, respectively). Both forms can clearly be distinguished based on the size of the initial chamber (large in A-form, small in B-form)
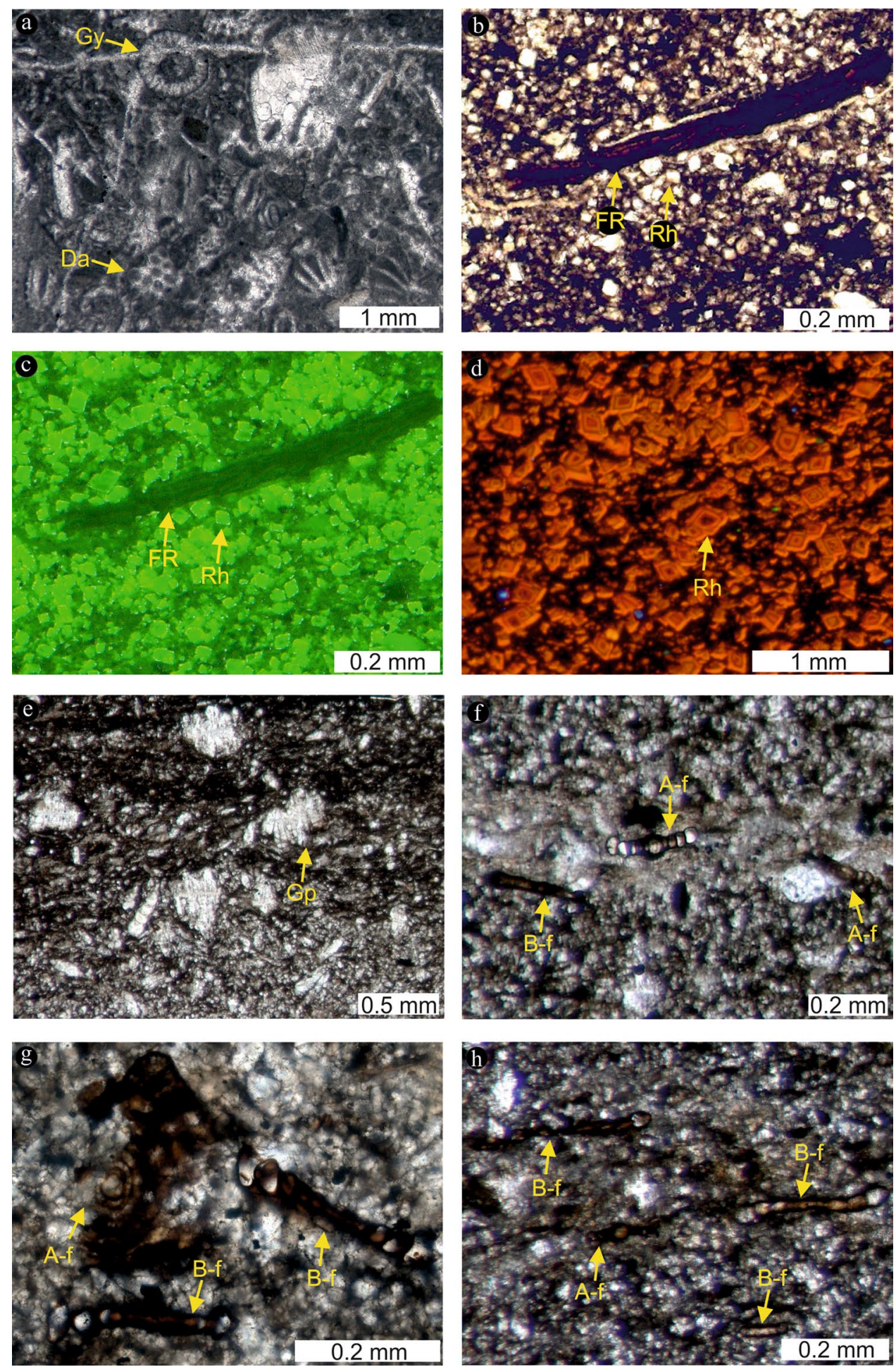

MF-4 Black marl (Fig. 7a-c)

Samples: $\mathrm{P}_{8}, \mathrm{P}_{12}, \mathrm{P}_{14}$ (Dalong Formation).

This MF can be divided into two sub-types (MF-4a and MF-4-b; see below).

MF-4a Black laminated marl with abundant fossil debris (Fig. 7a,b)-Sample: $\mathrm{P}_{8}$ (Dalong Formation). This MF subtype contains abundant fossil debris $(0.01-0.1 \mathrm{~mm})$ floating in a fine-grained matrix. Low $\mathrm{C}_{\text {carb }}$ and calculated $\mathrm{CaCO}_{3}$ contents $(2.46 \mathrm{wt} \%$ and $20.5 \mathrm{wt} \%$, respectively: Table 1) indicate that the matrix consists of carbonate and clay. Well-preserved thin-shelled bivalves and small benthic foraminifera with hyaline radial tests are enriched in certain layers (Fig. 7a). Some of the bivalve fossils in such layers are still intact (i.e., composed of both valves) 


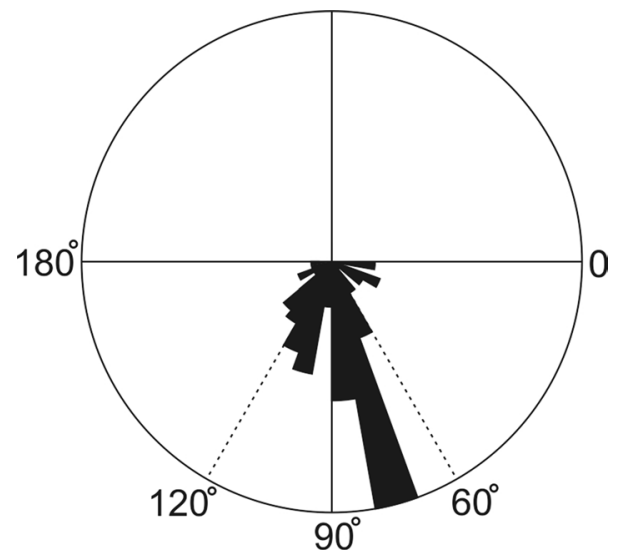

Fig. 5 Rose diagram showing angles between long axes of lenticularshaped pseudomorphs after gypsum and sedimentary bedding planes (measured in cross sections; $N=129$ ). Note that about $64 \%$ of the angles range between $60^{\circ}$ and $120^{\circ}$, suggesting that the gypsum crystals formed in-situ

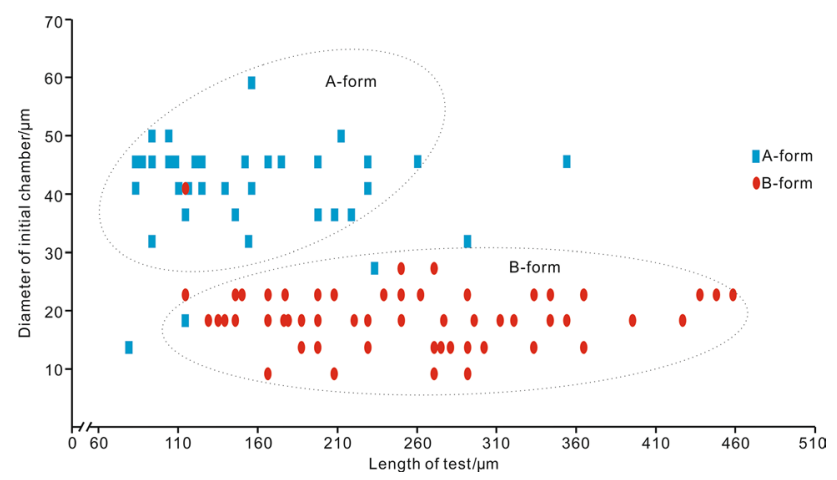

Fig. 6 Crossplot diagram of morphological parameters of Rectocornuspira specimens in MF-3 (length of test vs diameter of initial chamber; $N=113$ ). Note that specimens plot in two separate groups, supporting the interpretation as megalospheric and microspheric stages (A- and B-form, respectively)

(Fig. 7b). Few lenticular and partly twinned calcite pseudomorphs after gypsum are preserved. Furthermore, the MF contains small $(25-100 \mu \mathrm{m})$ silicate mineral crystals.

$M F-4 b$ Black non-laminated marl with calcite and pyrite concretions (Fig. 7c)-Samples: $\mathrm{P}_{12}, \mathrm{P}_{14}$ (Dalong Formation). This MF subtype contains abundant $0.2-12 \mathrm{~mm}$ sized concretions composed of variable mixtures of calcite and pyrite in a fine-grained matrix (Fig. 7c). Low $\mathrm{C}_{\text {carb }}$ and calculated $\mathrm{CaCO}_{3}$ contents $(\leq 2.11 \mathrm{wt} \%$ and $\leq 17.6 \mathrm{wt} \%$, respectively: Table 1) indicate that the matrix consists of carbonate and clay. The concretions contain clasts, including dolomite rhombs. Abundant fragmented thin-shelled bivalves and small benthic foraminifera are observed. In addition, few fish remains and calcite pseudomorphs after gypsum occur.
Furthermore, the MF contains small $(25-100 \mu \mathrm{m})$ silicate mineral crystals.

MF-5 Gray non-laminated micrite with dolomite rhombs (Fig. 7d)

Samples: $\mathrm{P}_{16}$ (Dalong Formation); $\mathrm{T}_{1}, \mathrm{~T}_{3}, \mathrm{~T}_{5}, \mathrm{~T}_{6}, \mathrm{~T}_{8}$ (Daye Formation).

This MF contains small $(5-50 \mu \mathrm{m})$ rhombohedralshaped dolomite crystals (Figs. 7d, 8, 9) that show similar fluorescence and CL characteristics as those in MF-2 (Fig. 4c, d). Raman spectroscopy revealed that some of the dolomite rhombs (Fig. 9a, b) exhibit pyrite cores (Fig. 9a, c), which in turn encapsulate dolomite crystals (Fig. 9a, d). The MF contains a few specimens of Earlandia. A further feature are centimeter-sized concretions that encapsulate non-spicular demosponges and radiolarians. Notably, some of the concretions are surrounded by microbial calcite crusts.

MF-6 Gray float- to wackestone with ammonoids (Fig. $7 e-h$ ).

Samples: $\mathrm{T}_{11}, \mathrm{~T}_{12}, \mathrm{~T}_{14}, \mathrm{~T}_{16}, \mathrm{~T}_{17}, \mathrm{~T}_{18}$ (Daye Formation).

Carbonate components (mainly fossils) are typically $>0.1 \mathrm{~mm}$ in diameter. They are poorly rounded and moderately sorted. The most abundant fossils are ammonoids (Fig. 7e). Shells of these organisms provided substrates for non-spicular demosponges (Fig. 7e) and microbial calcite crusts (Fig. 7f). Other abundant components are thinshelled bivalves (Fig. 7g), gastropods, ostracods and radiolarians, the latter being locally densely packed (Fig. 7h).

\section{Bulk geochemical characterization}

The samples exhibit highly variable $\mathrm{C}_{\text {org }}$ contents that range between 0.04 and 4.18 wt\% (Fig. 2; Table 1). The highest $\mathrm{C}_{\text {org }}$ contents are observed in samples grouping into the MF-2 $\left(\mathrm{P}_{2}=2.91 \mathrm{wt} \%\right)$ and MF-4 $\left(\mathrm{P}_{12}=3.76 \mathrm{wt} \%\right.$ and $\left.\mathrm{P}_{8}=4.18 \mathrm{wt} \%\right) . \mathrm{C}_{\text {carb }}$ contents also vary profoundly, with values ranging from 1.36 to $11.96 \mathrm{wt} \%$ (corresponding to calculated $\mathrm{CaCO}_{3}$ contents of 11.3-99.7 wt\%: Fig. 2; Table 1). $\mathrm{C}_{\text {org }}$ and $\mathrm{CaCO}_{3}$ contents are negatively correlated (Fig. 2; Table 1).

\section{Stable isotopes $\left(\delta^{13} C_{\text {carb }}, \delta^{18} O_{\text {carb }}, \delta^{13} C_{\text {org }}\right)$}

$\delta^{13} \mathrm{C}_{\text {carb }}$ values of different mineral phases vary from 0.3 to 4.2\%o (Fig. 10; Table 2). $\delta^{18} \mathrm{O}_{\text {carb }}$ values range from -9.2 to $-1.6 \%$ (Fig. 10; Table 2). $\delta^{13} \mathrm{C}_{\text {carb }}$ and $\delta^{18} \mathrm{O}_{\text {carb }}$ do not exhibit a linear relationship, pointing against meteoric diagenesis (Bishop et al. 2014). A later fracture cement has a $\delta^{13} \mathrm{C}_{\text {carb }}$ value of $4.8 \%$ and a $\delta^{18} \mathrm{O}_{\text {carb }}$ value of $-6.9 \%$. The MF show systematically different $\delta^{13} \mathrm{C}_{\text {carb }}$ and $\delta^{18} \mathrm{O}_{\text {carb }}$ values (Fig. 10; Table 2). 
Fig. 7 Thin section images of microfacies (MF) 4-6. a-b MF-4a: Black laminated marl with abundant fossil debris. Some layers contain well-preserved thin-shelled bivalves (Bi) and small benthic foraminifera $(\mathrm{Fo})$ with hyaline radial tests (a). Other important features include intact bivalve fossils (Bi: b). c MF-4b: Black non-laminated marl with calcite and pyrite concretions (Co). d MF-5: Gray non-laminated micrite with dolomite rhombs (Rh). Rhombohedral-shaped crystals show similar CL characteristics as those in MF-2. e-h MF-6: Gray float- to wackestone with ammonoids (Am). Note that ammonoid shells served as substrates for non-spicular demosponges (Sp: e) and biofilms (as indicated by microbial calcite crusts, MC: f). Other abundant components include thin-shelled bivalves (Bi: $\mathbf{g}$ ), gastropods, ostracods and radiolarians.

Radiolarians (Ra) are locally densely packed (h)
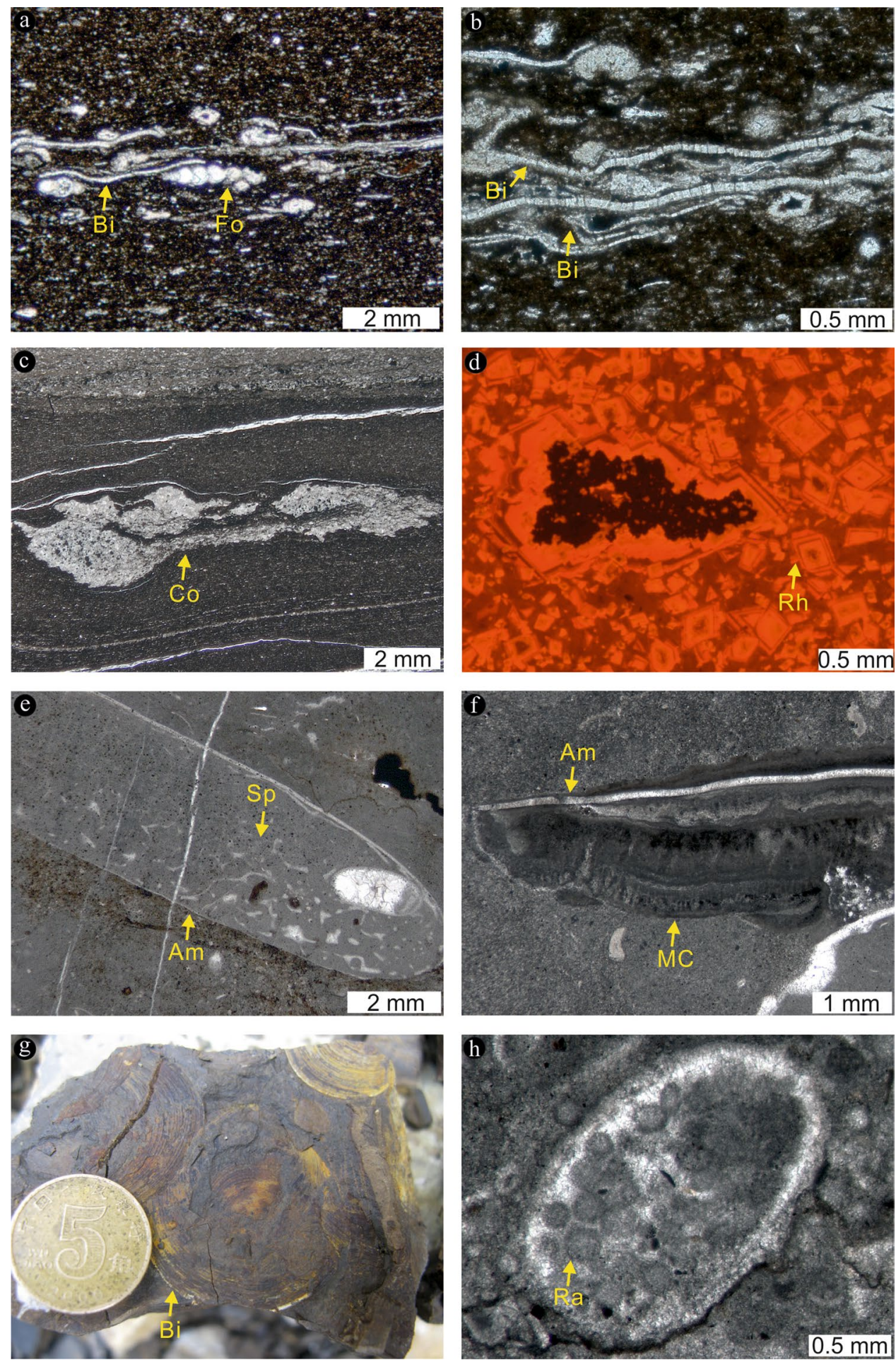

$\delta^{13} \mathrm{C}_{\text {org }}$ signatures of the samples vary between -27.4 and $-19.9 \%$ (Fig. 2; Table 1). Most values cluster around ca. $-25 \%$, but two samples show distinctly heavier signatures $\left(\mathrm{P}_{4}=-19.9 \%\right.$ o, $\mathrm{T}_{8}=-20.2 \%$ o: Fig. 2; Table 1).

\section{Discussion}

\section{Paleocommunities and -environments}

Assemblages of calcareous algae (e.g., Dasycladaceae, Gymnocodiaceae) and photosymbiont-bearing foraminifera (e.g., Fusulinidae) indicate that MF-1 was deposited in 
Table 1 Bulk geochemical data, including carbon stable isotope signatures of organic matter $\left(\delta^{13} \mathrm{C}_{\mathrm{org}}\right)$

\begin{tabular}{|c|c|c|c|c|c|c|c|c|c|c|c|c|}
\hline \multirow{2}{*}{$\begin{array}{l}\text { MF } \\
\text { Sample }\end{array}$} & \multicolumn{2}{|l|}{ MF1 } & \multicolumn{4}{|l|}{ MF2 } & \multicolumn{3}{|l|}{ MF3 } & \multirow{2}{*}{$\begin{array}{l}\text { MF-4a } \\
\text { P8 }\end{array}$} & \multicolumn{2}{|l|}{ MF-4b } \\
\hline & $\mathrm{P}_{\mathrm{b} 1}$ & P1 & $\mathrm{P} 2$ & P3 & \multicolumn{2}{|l|}{ P4 } & P5 & $\mathrm{P} 7$ & P9 & & $\mathrm{P} 12$ & $\mathrm{P} 14$ \\
\hline $\mathrm{C}_{\mathrm{org}}(\mathrm{wt} \%)$ & 0.04 & 0.30 & 2.91 & 0.62 & 1.85 & & 0.74 & 0.82 & 0.92 & 4.18 & 3.76 & 1.08 \\
\hline $\mathrm{C}_{\text {carb }}(\mathrm{wt} \%)$ & 11.96 & 11.03 & 6.89 & 10.7 & 8.14 & & 9.61 & 10.02 & 9.69 & 2.46 & 2.11 & 1.36 \\
\hline Calculated $\mathrm{CaCO}_{3}(\mathrm{wt} \%)$ & 99.7 & 91.9 & 57.4 & 89.2 & 67.8 & & 80.1 & 83.5 & 80.7 & 20.5 & 17.6 & 11.3 \\
\hline Averaged $\mathrm{CaCO}_{3}(\mathrm{wt} \%)$ & 95.8 & & 71.5 & & & & 81.4 & & & 16.5 & & \\
\hline$\delta^{13} \mathrm{C}_{\mathrm{org}}(\% o)$ & -25.6 & -26.5 & -26.5 & -26.8 & -19 & & -27.1 & -27.4 & -26.8 & -26.5 & -27.0 & -26.3 \\
\hline MF & MF-5 & & & & & & MF-6 & & & & & \\
\hline Sample & P16 & $\mathrm{T} 1$ & T3 & T5 & T6 & $\mathrm{T} 8$ & T11 & T12 & $\mathrm{T} 14$ & T16 & $\mathrm{T} 17$ & $\mathrm{~T} 18$ \\
\hline $\mathrm{C}_{\mathrm{org}}(\mathrm{wt} \%)$ & 0.32 & 0.21 & 0.44 & 0.25 & 0.23 & 0.17 & 0.16 & 0.25 & 0.10 & 0.30 & 0.18 & 0.19 \\
\hline $\mathrm{C}_{\text {carb }}(\mathrm{wt} \%)$ & 8.39 & 8.05 & 8.52 & 8.11 & 8.39 & 6.47 & 8.95 & 9.06 & 9.96 & 8.25 & 7.84 & 9.84 \\
\hline Calculated $\mathrm{CaCO}_{3}(\mathrm{wt} \%)$ & 69.9 & 67.1 & 71.0 & 67.6 & 69.9 & 53.9 & 74.6 & 75.5 & 83.0 & 68.7 & 65.3 & 82.0 \\
\hline Averaged $\mathrm{CaCO}_{3}(\mathrm{wt} \%)$ & 66.6 & & & & & & 74.9 & & & & & \\
\hline$\delta^{13} \mathrm{C}_{\mathrm{org}}(\% o)$ & -25.2 & -26.6 & -26.1 & -26.8 & -25.1 & -20.2 & -24.8 & -23.9 & -25.7 & -27.3 & -25.5 & -26.8 \\
\hline
\end{tabular}

Fig. 8 Field emission scanning electron microscopy-X-ray spectrometry (Fe-SEM EDX) images of dolomite rhombs in MF-5. a SEM image. b Calcium distribution. c Magnesium distribution. d Sulfur distribution
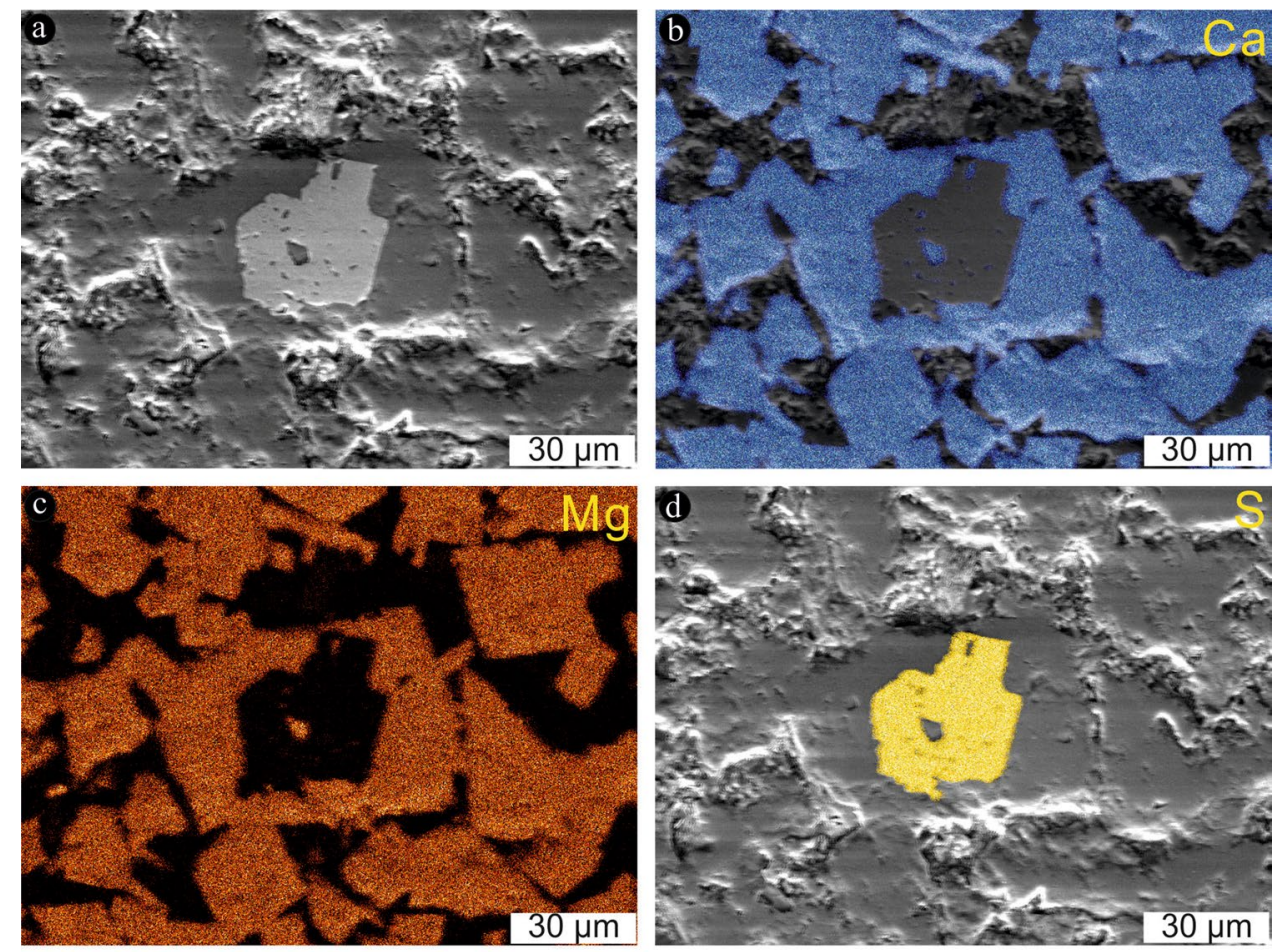

oxygenated shallow water environments under tropical to subtropical conditions (Hottinger 1997; Langer and Hottinger 2000; Flügel 2010) (Fig. 4a). In such environments, oxygenic phototrophs typically dominate primary productivity, which is consistent with $\delta^{13} \mathrm{C}_{\text {org }}$ values of about $-26 \%$ o (Fig. 2; Table 1). A significant uptake of ${ }^{12} \mathrm{C}$ by autotrophic primary producers usually results in a concurrent enrichment of ${ }^{13} \mathrm{C}$ in the water body, which is well in line with the high $\delta^{13} \mathrm{C}_{\text {carb }}$ value of $4.2 \%$ (Fig. 10; Table 2).
Occurrences of planktonic radiolarians and nektonic ammonoids in MF-2-3 and MF-5-6 (Figs. 7e, h, 11) suggest somewhat greater water depths than for MF-1. This observation is in good agreement with the presence of intact, thin-shelled bivalves that were preserved in gravity flow deposits (MF-4a) (Figs. 7b, 11) and indicate a relatively deep, low-energy environment. The presence of low-oxygentolerant and potentially chemosymbiont-bearing organisms such as non-spicular demosponges and thin-shelled bivalves such as Claraia in MF-2-6 (see Wignall and Hallam 1992; 
Fig. 9 Raman spectroscopic features of dolomite rhombs in MF-5. a Positions of point measurements shown in b-d (reflected light image). Note that the dolomite rhombs (b) exhibit pyrite cores (c), that in turn encapsulate dolomite (d)
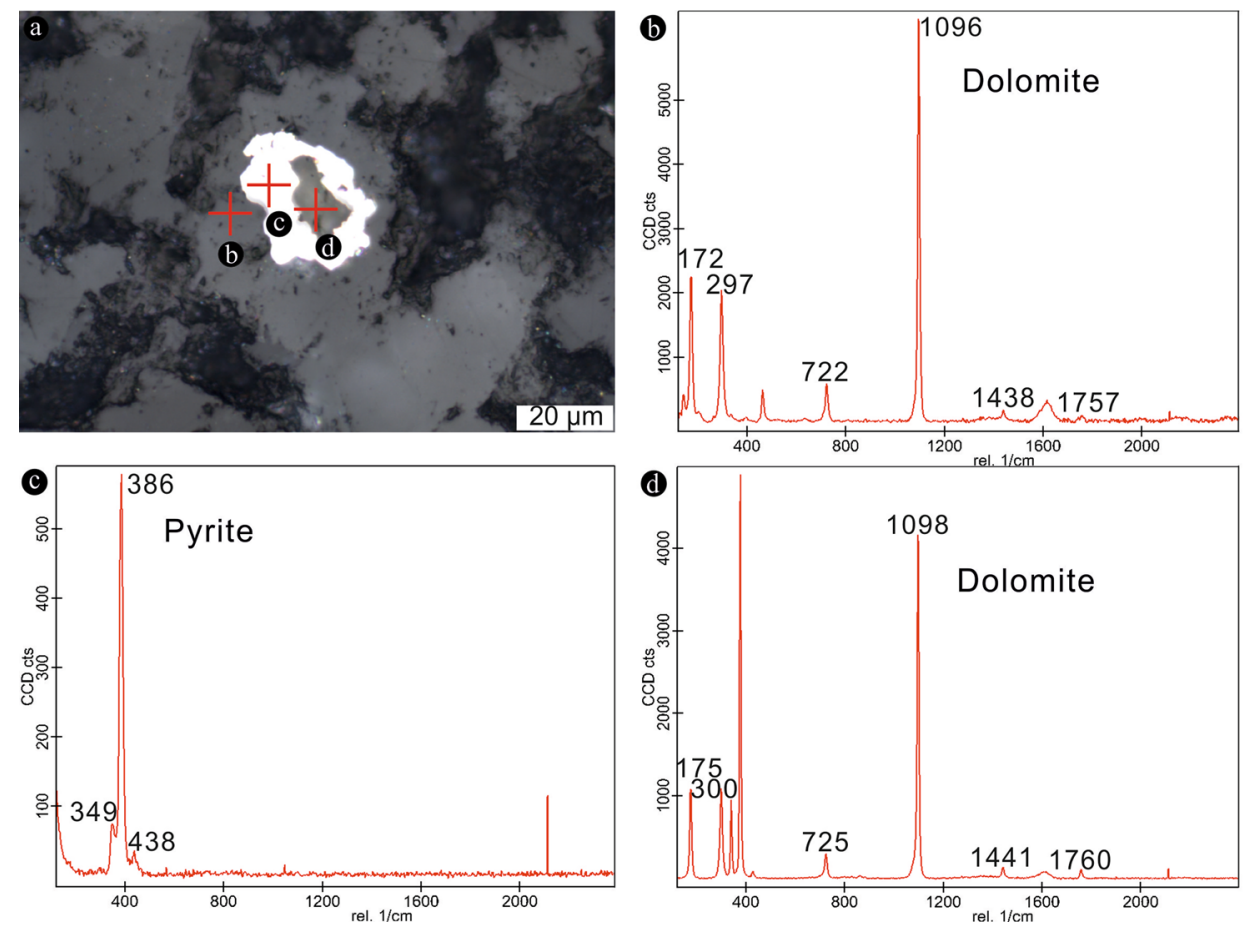

Hoffmann et al. 2005; McRoberts 2010; Zhao et al. 2013; Mills et al. 2014; Huang et al. 2018; Figs.7a, b, e, g, 11) possibly reflect dysoxic to anoxic conditions at the seafloor. In the light of these findings, $\delta^{13} \mathrm{C}_{\text {org }}$ values of about $-20 \%$ in beds $\mathrm{P}_{4}$ and $\mathrm{T}_{8}$ (Fig. 2; Table 1) might fingerprint significant contributions of organic matter by anoxygenic phototrophic bacteria to the bulk biomass (Preuß et al. 1989; Posth et al. 2017).

Porcelaneous Miliolina (e.g., abundant Rectocornuspira in MF-3, rare Earlandia in MF-5: Figs. 4f, 11) are ecologic opportunists commonly related to hypersaline conditions (Hallam and Wignall 1997; Groves and Altiner 2005;

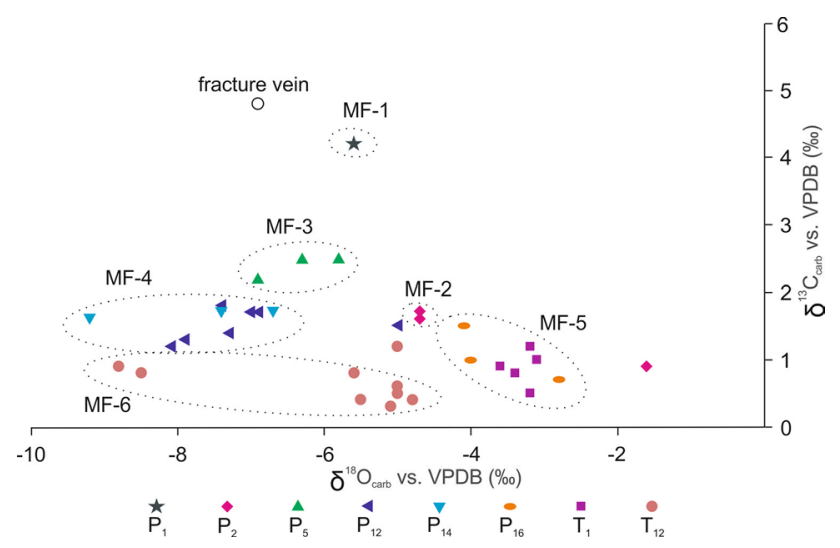

Fig. 10 Carbon stable isotope and oxygen stable isotope data for individual carbonate phases in different samples. Note that the MF show systematically different $\delta^{13} \mathrm{C}_{\text {carb }}$ and $\delta^{18} \mathrm{O}_{\text {carb }}$ values (circled areas)
Flügel 2010). Elevated salinities are possibly also indicated by the presence of calcite pseudomorphs after gypsum (highly abundant in MF-3, rare in MF-2 and -4: Fig. 4e). About $64 \%$ of the calcite pseudomorphs exhibit angles of $60^{\circ}-120^{\circ}$ between their long main axes and the sedimentary bedding plane ( $N=129$; Fig. 5$)$, indicating that gypsum formed in situ (Warren 2006). Gypsum has also been observed in P-TrCI strata of the Meishan section in South China (Liang 2002; Kaiho et al. 2006; Chen et al. 2015; Li and Jones 2017). Alternatively, the gypsum may be formed through the re-oxidation of hydrogen sulfide, as observed in organic matter or methane rich sediments affected by a pronounced sulfate reduction (Lin et al. 2016). Furthermore, potential biomarkers of halophilic Archaea were found in $\mathrm{P}-\mathrm{Tr}$ boundary microbialites, suggesting that hypersaline conditions existed episodically in the upper water column of the Neo-Tethys (Heindel et al. 2018). Taken together, these findings indicate elevated salinities in parts of the Neo- and Paleo-Tethys, including in the Xiakou area.

\section{Sedimentary factories}

Carbonate production has been linked to biological processes throughout Earth's history (James and Ginsburg 1979; Flügel 2010). Carbonate rocks can be formed from the accumulation of the skeletons of eukaryotic organisms. This process thus depends on the controlled precipitation of inorganic minerals by living organisms; that is, "biomineralization" sensu stricto (Mann 2002). Carbonate rocks can also be formed by the microbially induced precipitation 


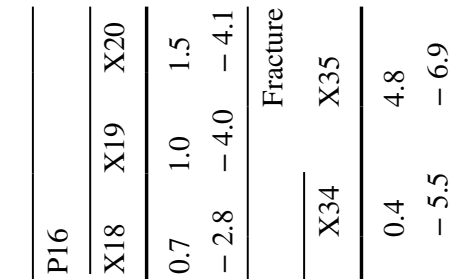

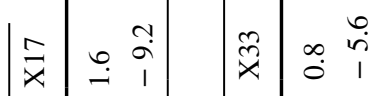

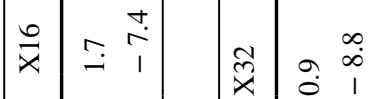

$$
\begin{aligned}
& \pm \frac{n}{x}=\begin{array}{l}
\hat{b} \\
-1
\end{array}
\end{aligned}
$$

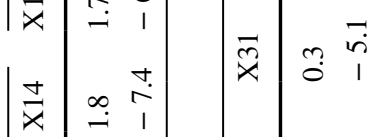

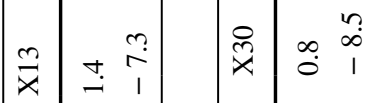

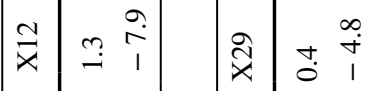

$$
\begin{aligned}
& \exists=\underline{a}
\end{aligned}
$$

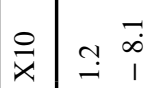

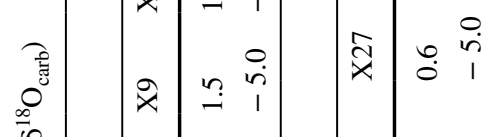

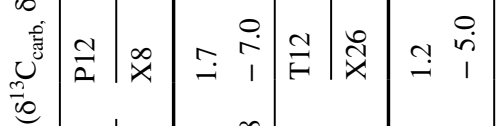

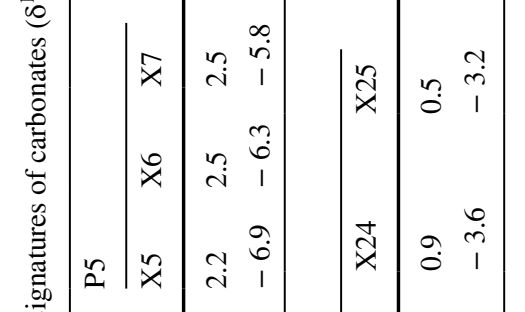

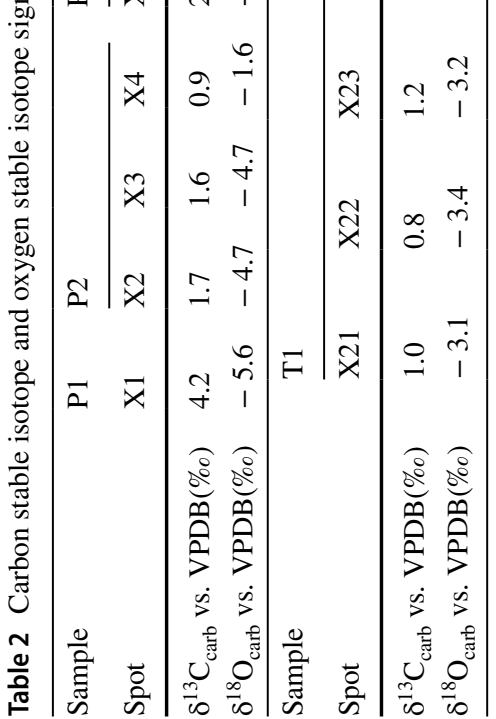

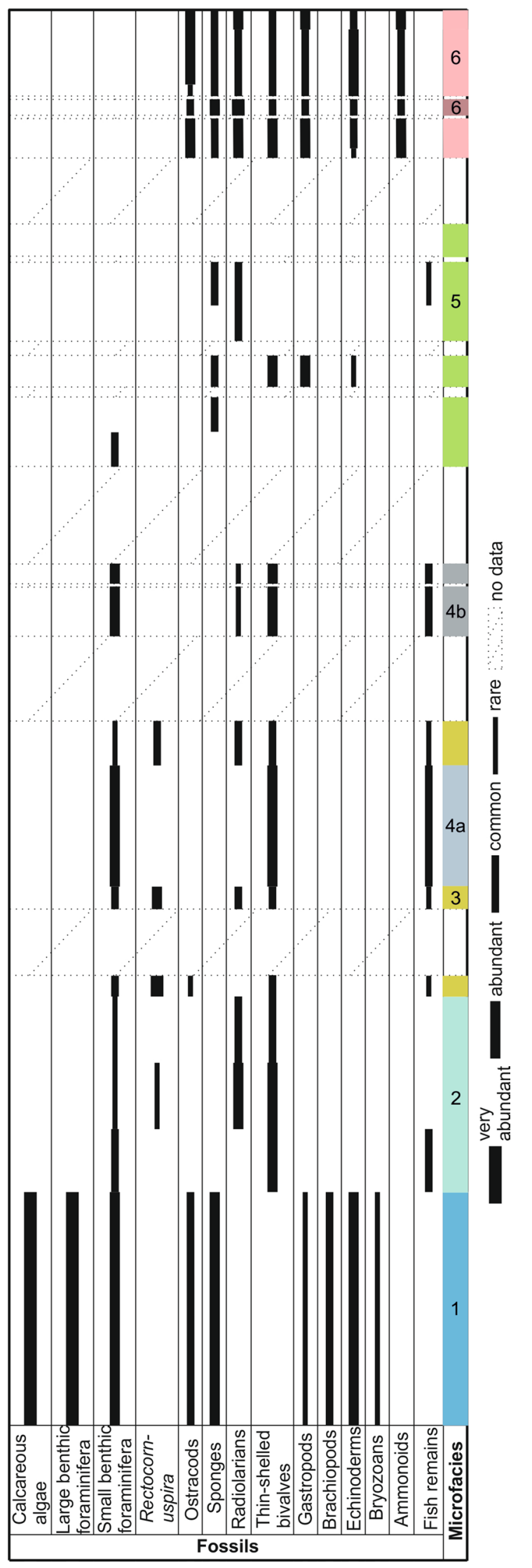

Fig. 11 Distribution of fossils in different microfacies from the Xiakou section 
of calcium carbonate. This process is related to chemical changes induced by metabolic activity, and commonly linked to exopolymeric substances (EPS) formed by microbial communities (Arp et al. 2001; Reitner et al. 2001; Riding 2000).

Carbonate precipitation can also be induced by organic matter (i.e., "organomineralization"). Typical products are autochthonous fine-grained carbonate ("automicrite") and/ or rhombohedral crystals (Addadi and Weiner 1985; Reitner 1993; Reitner et al. 1995a, b, 2000, 2001; Trichet and Défarge 1995). Automicrite is easily confused with micrite consisting of allochthonous carbonate material ("allomicrite") but can commonly be distinguished by specific features (e.g., clotted and mottled fabrics, peloidal microstructures, strong fluorescence) (Wolf 1965; Reitner 1993; Reitner et al. 1995b). Tightly packed dolomite rhombs showing CL zoning are usually interpreted as diagenetic cements (Flügel 2010). However, "organomineralization" can also form rhombs (Addadi and Weiner 1985; Trichet and Défarge 1995). The observed organic matter enrichments in the rims of the dolomite rhombs (Fig. 4c) might imply that organic templates influenced crystal growth. In this view, the dolomite rhombs at Xiakou could be considered organominerals.

The investigated succession begins with a eukaryote-controlled carbonate factory, where the remains of shell-forming organisms significantly contribute to the sediment (MF-1: Figs. 4a, 11, 12a; Table 1). Automicrite is relatively rare and mainly restricted to taphonomic degradation of organisms such as sponges. In the section immediately above, the eukaryote-controlled sediment factory declined and was gradually replaced by fine-grained carbonate with abundant rhombohedral dolomite crystals (MF-2: Figs. 4b-d, 12b). The fine-grained matrix of MF-2 and MF-3 may also be automicrite. Moving upward in the section, the organomineralization-based carbonate factory collapses, as reflected in distinct black marls with only $16.5 \mathrm{wt} \%$ carbonate (MF-4: Fig. 12b; Table 1). Following this interval, and just below the $\mathrm{P}-\mathrm{Tr}$ boundary, carbonate formation started again. These carbonates $\left(\mathrm{Bed}_{16}\right)$ contain abundant rhombohedral dolomite crystals that are similar to ones found in MF-2 and also interpreted as organominerals (Figs. 7d, 12b; Table 1). This facies then passes into a mixed carbonate factory, where organomineralization and biomineralization are almost equally important (Figs. 7e-h, 11, 12c; Table 1).

\section{Geobiological implications for the P-TrCl}

In South China, paleontological evidence and $\delta^{13} \mathrm{C}_{\text {carb }}$ data indicate the possibility of one (Jin et al. 2000; Shen et al. 2019), two (Xie et al. 2007; Yin et al. 2012; Song et al. 2013; Chen et al. 2015), or even three extinction pulses (Yang et al. 1991) in the P-TrCI. The Xiakou section records a dramatic decline in calcifying eukaryote diversity after Bed $\mathrm{P}_{1}$ (Figs. 2, 11). This development was accompanied by a distinct change in the carbonate factory from eukaryotecontrolled to organomineralization (Fig. 12a, b). Carbonate formation by organomineralization continues until Bed $\mathrm{P}_{9}$, while the diversity of calcifying eukaryotes remains low. Carbonate sedimentation starts again with Bed $\mathrm{P}_{16}$ (Figs. 2, $12 b)$. The diversity of calcifying eukaryotes, however, does not increase until Bed $\mathrm{T}_{11}$ (Figs. 2, 11, 12c). The apparent
Fig. 12 Integrative ecological model for the Xiakou area during the Permian-Triassic Critical Interval (P-TrCI). a Oxygenated shallow water environments and a biomineralization-dominated carbonate factory (MF-1). b Deeper water environments with episodically depleted oxygen, elevated salinities, and possibly euxinic conditions (MF-2-5). Carbonate was mainly formed via organomineralization (MF-2-3, 5 ), but this factory was intermittently interrupted (MF-4). c Deeper water environments and a mixed carbonate factory, with organomineralization and biomineralization being equally important (MF-6)

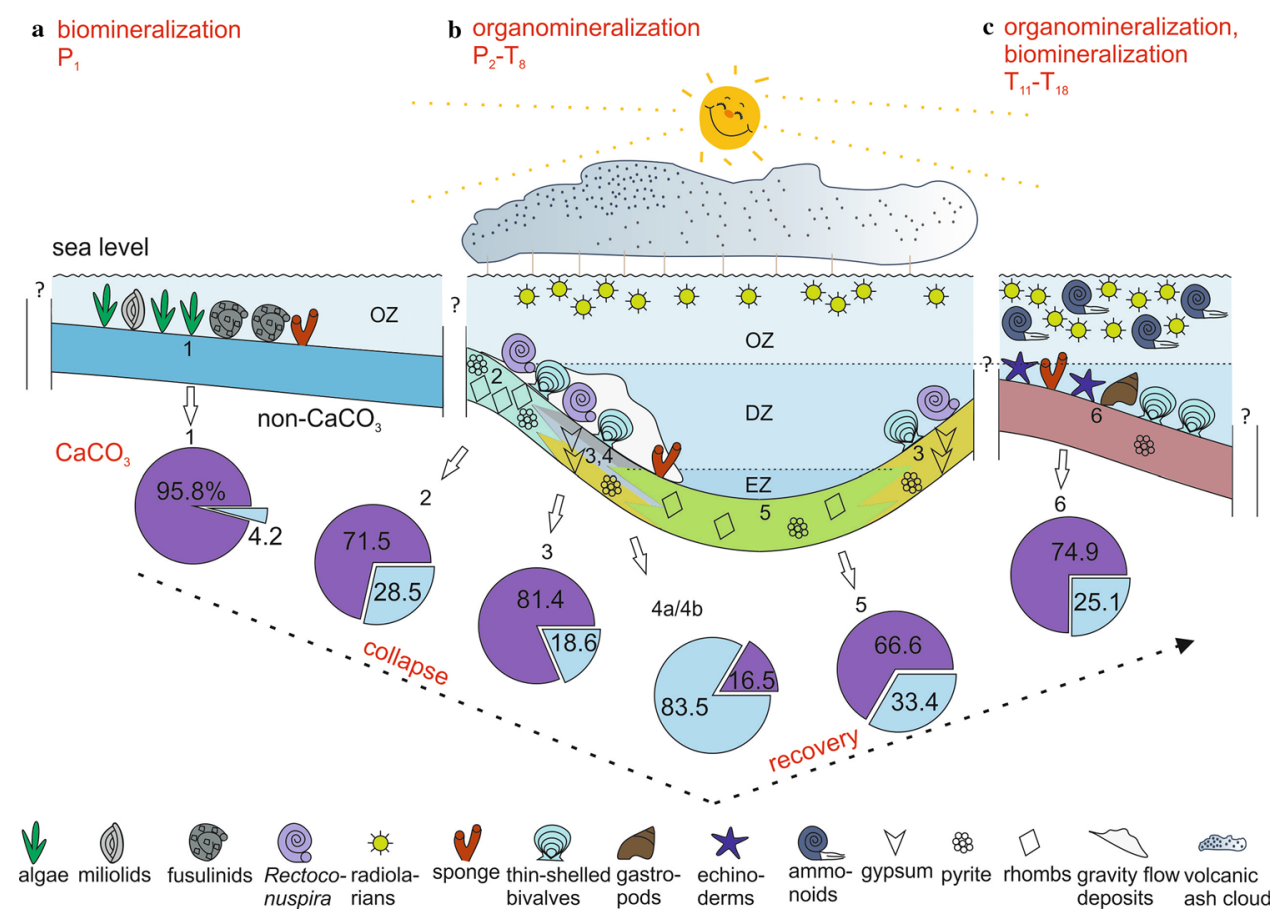


offset between carbonate sedimentation and biodiversity highlights the complexity of ecosystem change (Muscente et al. 2018) during the $\mathrm{P}-\mathrm{TrCI}$ and supports the speculation that interpretations of the $\mathrm{P}-\mathrm{Tr}$ extinction event might be oversimplified (cf. Erwin 1994; Stanley 2016).

At Xiakou, a dramatic decline in the diversity of calcifying eukaryotes occurred at the transition from Bed $\mathrm{P}_{1}$ to Bed $\mathrm{P}_{2}$ (Figs. 2, 11). The drop in diversity was possibly accompanied by temporary euxinic conditions, as suggested by $\delta^{13} \mathrm{C}_{\text {org }}$ signatures possibly indicative of anoxygenic phototrophs (ca. - 20\%o: Fig. 2; Table 1). Both developments fall into the Clarkina changxingensis conodont zone (see Zhao et al. 2013) and may be related to the P-Tr extinction event. At Meishan, however, the diversity of calcifying eukaryotes does not profoundly change until the uppermost part of the younger Clarkina yini conodont zone (Yin et al. 2001; Chen et al. 2015) (Fig. 2). Inhospitable conditions for aerobic life existed in the photic zone at Meishan for 1.5 million years prior to the widespread biological extinction, as indicated by occurrences of the lipid biomarker isorenieratane (Cao et al. 2009). The offsets in timing between the Xiakou and Meishan sections challenge the common assumption that the $\mathrm{P}-\mathrm{Tr}$ mass extinction event occurred simultaneously around the globe, particularly as both sections were closely located during the $\mathrm{P}-\mathrm{TrCI}$.

\section{Conclusion}

The Permian-Triassic mass extinction is characterized by a potentially catastrophic decline of biodiversity in marine and terrestrial ecosystems. Here we presented findings from Permian-Triassic strata exposed in the Xiakou area (South China). The succession begins with a eukaryote-controlled carbonate factory (Bed $\mathrm{P}_{1}$ ). Carbonate formation by organomineralization continues until Bed $\mathrm{P}_{9}$. Carbonate sedimentation starts again with organomineralization in Beds $\mathrm{P}_{16}-\mathrm{T}_{8}$ and develops into a mixed carbonate factory, with organomineralization and biomineralization being almost equally important in Beds $\mathrm{T}_{11}-\mathrm{T}_{18}$. Bed $\mathrm{P}_{1}$ was deposited in oxygenated shallow water environments, while Beds $\mathrm{P}_{2}-\mathrm{T}_{18}$ were deposited in somewhat deeper environments, some of which episodically exhibited elevated salinities, oxygen depletion, and, possibly, euxinic conditions. Taken together, our studies of the sedimentary strata at Xiakou indicate an apparent disparity between carbonate sedimentation and biodiversity. Moreover, the timing of biodiversity and environmental change at Xiakou is different from that observed at the type section in Meishan, despite the proximity of the two locations. Together, these findings highlight the complexity of ecosystem change during the $\mathrm{P}-\mathrm{TrCI}$ due to strong local influences, supporting the suspicion that interpretations of the $\mathrm{P}-\mathrm{Tr}$ extinction event might be oversimplified.

Acknowledgements We appreciate constructive comments and suggestions from M. Reich, J. Peckmann and an anonymous reviewer. A. Munnecke, A.L. Claußen, D. Birgel, E. Jarochowska, G. Mathes, L.M. Baumann, M. Natalicchio, P. Suarez-Gonzalez, and S. Kiel are thanked for helpful discussions. D. Grabow, J. Luo, N. Höche, Y. He, Z-Q. Chen, H. Mei, B. Feng and G. Wu are acknowledged for field assistance. A. Hackmann, A. Pack, A. Reimer, B. Röring, C. Conradt, D. Hause-Reitner, D. Kohl, J. Dyckmans, J. Schönig, K. Lünsdorf and W. Dröse are thanked for lab assistance. This study was financially supported by the China Council Scholarship (CSC).

Funding Open Access funding enabled and organized by Projekt DEAL.

Open Access This article is licensed under a Creative Commons Attribution 4.0 International License, which permits use, sharing, adaptation, distribution and reproduction in any medium or format, as long as you give appropriate credit to the original author(s) and the source, provide a link to the Creative Commons licence, and indicate if changes were made. The images or other third party material in this article are included in the article's Creative Commons licence, unless indicated otherwise in a credit line to the material. If material is not included in the article's Creative Commons licence and your intended use is not permitted by statutory regulation or exceeds the permitted use, you will need to obtain permission directly from the copyright holder. To view a copy of this licence, visit http://creativecommons.org/licenses/by/4.0/.

\section{References}

Adachi, N., Y. Asada, Y. Ezaki, and J. Liu. 2017. Stromatolites near the Permian-Triassic boundary in Chongyang, Hubei province, South China: A geobiological window into palaeo-oceanic fluctuations following the end-permian extinction. Palaeogeography, Palaeoclimatology, Palaeoecology 475: 55-69.

Addadi, L., and S. Weiner. 1985. Interactions between acidic proteins and crystals: Stereochemical requirements in biomineralization. Proceedings of the National Academy of Sciences 82: $4110-4114$.

Alroy, J., M. Aberhan, D.J. Bottjer, M. Foote, F.T. Fürsich, P.J. Harries, A.J.W. Hendy, S.M. Holland, L.C. Ivany, W. Kiessling, M.A. Kosnik, C.R. Marshall, A.J. McGowan, A.I. Miller, T.D. Olszewski, M.E. Patzkowsky, S.E. Peters, L. Villier, P.J. Wagner, N. Bonuso, P.S. Borkow, B. Brenneis, M.E. Clapham, L.M. Fall, C.A. Ferguson, V.L. Hanson, A.Z. Krug, K.M. Layou, E.H. Leckey, S. Nürnberg, C.M. Powers, J.A. Sessa, C. Simpson, A. Tomašových, and C.C. Visaggi. 2008. Phanerozoic trends in the global diversity of marine invertebrates. Science 321: 97-100.

Arp, G., A. Reimer, and J. Reitner. 2001. Photosynthesis-induced biofilm calcification and calcium concentrations in Phanerozoic oceans. Science 292: 1701-1704.

Benton, M.J., and R.J. Twitchett. 2003. How to kill (almost) all life: the end-Permian extinction event. Trends in Ecology and Evolution 18: 358-365.

Bernasconi, S.M., I. Meier, S. Wohlwend, P. Brack, P.A. Hochuli, H. Bläsi, U.G. Wortmann, and K. Ramseyer. 2017. An evaporitebased high-resolution sulfur isotope record of Late Permian and Triassic seawater sulfate. Geochimica et Cosmochimica Acta 204: 331-349.

Bishop, J.W., D.A. Osleger, I.P. Montañez, and D.Y. Sumner. 2014. Meteoric diagenesis and fluid-rock interaction in the Middle 
Permian Capitan backreef: Yates Formation, Slaughter Canyon, New Mexico. American Association of Petroleum Geologists, Bulletin 98: 1495-1519.

Bottjer, D.J., M.E. Clapham, M.L. Fraiser, and C.M. Powers. 2008. Understanding mechanisms for the end-Permian mass extinction and the protracted Early Triassic aftermath and recovery. The Geological Society of America Today 18: 4-10.

Brennecka, G.A., A.D. Herrmann, T.J. Algeo, and A.D. Anbar. 2011. Rapid expansion of oceanic anoxia immediately before the endPermian mass extinction. Proceedings of the National Academy of Sciences 108: 17631-17634.

Broadley, M.W., P.H. Barry, C.J. Ballentine, L.A. Taylor, and R. Burgess. 2018. End-Permian extinction amplified by plume-induced release of recycled lithospheric volatiles. Nature Geoscience 11: 682-687.

Burgess, S.D., and S.A. Bowring. 2015. High-precision geochronology confirms voluminous magmatism before, during, and after Earth's most severe extinction. Science Advances 1: e1500470.

Burgess, S.D., J.D. Muirhead, and S.A. Bowring. 2017. Initial pulse of Siberian Traps sills as the trigger of the end-Permian mass extinction. Nature Communications 8: 164.

Cao, C., G.D. Love, L.E. Hays, W. Wang, S. Shen, and R.E. Summons. 2009. Biogeochemical evidence foreuxinic oceans and ecological disturbance presaging the end-Permian mass extinction event. Earth and Planetary Science Letters 281: 188-201.

Chen, Z.-Q., and M.J. Benton. 2012. The timing and pattern of biotic recovery following the end-Permian mass extinction. Nature Geoscience 5: 375-383.

Chen, Z.-Q., H. Yang, M. Luo, M.J. Benton, K. Kaiho, L. Zhao, Y. Huang, K. Zhang, Y. Fang, H. Jiang, H. Qiu, Y. Li, C. Tu, L. Shi, L. Zhang, X. Feng, and L. Chen. 2015. Complete biotic and sedimentary records of the Permian-Triassic transition from Meishan Section, South China: Ecologically assessing mass extinction and its aftermath. Earth-Science Reviews 149: 67-107.

Chen, Z.-Q., C. Tu, Y. Pei, J. Ogg, Y. Fang, S. Wu, X. Feng, Y. Huang, Z. Guo, and H. Yang. 2019. Biosedimentological features of major microbe-metazoan transitions (MMTs) from Precambrian to Cenozoic. Earth-Science Reviews 189: 21-50.

Clarkson, M.O., S.A. Kasemann, R.A. Wood, T.M. Lenton, S.J. Daines, S. Richoz, F. Ohnemueller, A. Meixner, S.W. Poulton, and E.T. Tipper. 2015. Ocean acidification and the Permo-Triassic mass extinction. Science 348: 229-232.

Elrick, M., V. Polyak, T.J. Algeo, S. Romaniello, Y. Asmerom, A.D. Herrmann, A.D. Anbar, L. Zhao, and Z.-Q. Chen. 2017. Globalocean redox variation during the middle-late Permian through Early Triassic based on uranium isotope and $\mathrm{Th} / \mathrm{U}$ trends of marine carbonates. Geology 45: 163-166.

Erwin, D.H. 1994. The Permo-Triassic extinction. Nature 367: 231-236.

Ezaki, Y., J. Liu, and N. Adachi. 2003. Earliest Triassic microbialite micro to megastructures in the Huaying area of Sichuan Province, South China: implications for the nature of oceanic conditions after the end-Permian extinction. Palaios 18: 388-402.

Ezaki, Y., J. Liu, T. Nagano, and N. Adachi. 2008. Geobiological aspects of the earliest Triassic microbialites along the southern periphery of the tropical Yangtze Platform: Initiation and cessation of a microbial regime. Palaeogeography, Palaeoclimatology, Palaeoecology 23: 356-369.

Fan, J.-X., S.-Z. Shen, D.H. Erwin, P.M. Sadler, N. MacLeod, Q.-M. Cheng, X.-D. Hou, J. Yang, X.-D. Wang, Y. Wang, H. Zhang, X. Chen, G.-X. Li, Y.-C. Zhang, Y.-K. Shi, D.-X. Yuan, Q. Chen, L.-N. Zhang, C. Li, and Y.-Y. Zhao. 2020. A high-resolution summary of Cambrian to Early Triassic marine invertebrate biodiversity. Science 367: 272-277.

Fang, Y., Z.-Q. Chen, S. Kershaw, H. Yang, and M. Luo. 2017. Permian-Triassic boundary microbialites at Zuodeng Section,
Guangxi Province, South China: Geobiology and palaeoceanographic implications. Global and Planetary Change 152: 115-128.

Feng, Z., Y. Yang, and Z. Jin. 1997. Lithofacies paleogeoraphy of Permian of South China. Beijing: China University of Petroleum Press.

Flügel, E. 2010. Microfacies of carbonate rocks. Heidelberg/Dordrecht/ London/New York: Springer.

Forel, M.B. 2013. The Permian-Triassic mass extinction: Ostracods (Crustacea) and microbialites. Comptes Rendus Geosciences 345: 203-211.

Foster, W.J., D.J. Lehrmann, M. Yu, and R.C. Martindale. 2019. Facies selectivity of benthic invertebrates in a Permian/Triassic boundary microbialite succession: Implications for the "microbialite refuge" hypothesis. Geobiology 17: 523-535.

Foster, W.J., K. Heindel, S. Richoz, J. Gliwa, D.J. Lehrmann, A. Baud, T. Kolar-Jurkovšek, D. Aljinović, B. Jurkovšek, D. Korn, R.C. Martindale, and J. Peckmann. 2020. Suppressed competitive exclusion enabled the proliferation of Permian/Triassic boundary microbialites. The Depositional Record 6: 62-74.

Fraiser, M.L., M.E. Clapham, and D.J. Bottjer. 2011. Mass Extinctions and Changing Taphonomic Processes: Fidelity of the Guadalupian, Lopingian, and Early Triassic Fossil Records. In Taphonomy: process and bias through time, eds. P.A. Allison and D.J. Bottjer, 569-590. Dordrecht/Heidelberg/London/New York: Springer.

Goldstein, S.T. 1999. Foraminifera: A biological overview. In Modern foraminifera, ed. B.K. Sen Gupta, 37-55. Dordrecht: Springer.

Grasby, S.E., J. Knies, B. Beauchamp, D.P.G. Bond, P. Wignall, and Y. Sun. 2019. Global warming leads to Early Triassic nutrient stress across northern Pangea. The Geological Society of America Bulletin 132: 943-954.

Grice, K., C. Cao, G.D. Love, M.E. Böttcher, R.J. Twitchett, E. Grosjean, R.E. Summons, S.C. Turgeon, W. Dunning, and Y. Jin. 2005. Photic zone euxinia during the Permian-Triassic superanoxic event. Science 307: 706-709.

Groves, J.R., and D. Altiner. 2005. Survival and recovery of calcareous foraminifera pursuant to the end-Permian mass extinction. Comptes Rendus Palevol 4: 487-500.

Hallam, A., and P.B. Wignall. 1997. Mass extinctions and their aftermath. Oxford/New York/Tokyo: Oxford University Press.

Heindel, K., S. Richoz, D. Birgel, R. Brandner, A. Klügel, L. Krystyn, A. Baud, M. Horacek, T. Mohtat, and J. Peckmann. 2015. Biogeochemical formation of calyx-shaped carbonate crystal fans in the subsurface of the Early Triassic seafloor. Gondwana Research 27: 840-861.

Heindel, K., W.J. Foster, S. Richoz, D. Birgel, V.J. Roden, A. Baud, R. Brandner, L. Krystyn, T. Mohtat, E. Koşun, R.J. Twitchett, J. Reitner, and J. Peckmann. 2018. The formation of microbialmetazoan bioherms and biostromes following the latest Permian mass extinction. Gondwana Research 61: 187-202.

Hinojosa, J.L., S.T. Brown, J. Chen, D.J. DePaolo, A. Paytan, S.-Z. Shen, and J.L. Payne. 2012. Evidence for end-Permian ocean acidification from calcium isotopes in biogenic apatite. Geology 40: 743-746.

Hoffmann, F., O. Larsen, V. Thiel, H.T. Rapp, T. Pape, W. Michaelis, and J. Reitner. 2005. An anaerobic world in sponges. Geomicrobiology Journal 22: 1-10.

Hottinger, L. 1997. Shallow benthic foraminiferal assemblages as signals for depth of their deposition and their limitations. Bulletin de la Société Géologique de France 168: 491-505.

Huang, Y., Z.-Q. Chen, P.B. Wignall, and L. Zhao. 2017. Latest Permian to Middle Triassic redox condition variations in ramp settings, South China: Pyrite framboid evidence. The Geological Society of America Bulletin 129: 229-243. 
Huang, Y., J. Tong, and M.L. Fraiser. 2018. A Griesbachian (Early Triassic) Mollusc Fauna from the Sidazhai Section, Southwest China, with Paleoecological Insights on the Proliferation of Genus Claraia (Bivalvia). Journal of Earth Science 29: 794-805.

Jablonski, D. 1986. Causes and consequences of mass extinctions: a comparative approach. In Dynamics of extinction, ed. D.K. Elliott, 183-229. New York: Wiley.

James, N.P., and R.N. Ginsburg. 1979. The seaward margin of Belize barrier and atolls reefs. Oxford: Blackwell.

Jin, Y., Y. Wang, W. Wang, Q. Shang, C. Cao, and D.H. Erwin. 2000. Pattern of marine mass extinction near the Permian-Triassic boundary in South China. Science 289: 432-436.

Joachimski, M.M., X. Lai, S. Shen, H. Jiang, G. Luo, B. Chen, J. Chen, and Y. Sun. 2012. Climate warming in the latest Permian and the Permian-Triassic mass extinction. Geology 40: 195-198.

Kaiho, K., Z.-Q. Chen, H. Kawahata, Y. Kajiwara, and H. Sato. 2006. Close-up of the end-Permian mass extinction horizon recorded in the Meishan section, South China: Sedimentary, elemental, and bioticcharacterization and a negative shift of sulfate sulfur isotope ratio. Palaeogeography, Palaeoclimatology, Palaeoecology 239: 396-405.

Kershaw, S., T. Zhang, and G. Lan. 1999. A? microbialite crust at the Permian-Triassic boundary in South China, and its palaeoenvironmental significance. Palaeogeography, Palaeoclimatology, Palaeoecology 146: 1-18.

Kershaw, S., S. Crasquin, Y. Li, P.Y. Collin, M.B. Forel, X. Mu, A. Baud, Y. Wang, S. Xie, F. Maurer, and L. Guo. 2012. Microbialites and global environmental change across the Permian-Triassic boundary: A synthesis. Geobiology 10: 25-47.

Knoll, A.H., R.K. Bambach, J.L. Payne, S. Pruss, and W.W. Fischer. 2007. Paleophysiology and end-Permian mass extinction. Earth and Planetary Science Letters 256: 295-313.

Langer, M.R., and L. Hottinger. 2000. Biogeography of selected "larger" foraminifera. Micropaleontology 46: 105-126.

Lehrmann, D.J. 1999. Early Triassic calcimicrobial mounds and biostromes of the Nanpanjiang Basin, South China. Geology 27: 359-362.

Lehrmann, D.J., J. Ramezani, S.A. Bowring, M.W. Martin, P. Montgomery, P. Enos, J.L. Payne, M.J. Orchard, H. Wang, and J. Wie. 2006. Timing of recovery from the end-Permian extinction: Geochronologic and biostratigraphic constraints from south China. Geology 34: 1053-1056.

Lehrmann, D.J., J.M. Bentz, T. Wood, A. Goers, R. Dhillon, S. Akin, X. Li, J.L. Payne, B.M. Kelley, K.M. Meyer, E.K. Schaal, M.B. Suarez, M. Yu, Y. Qin, R. Li, M. Minzoni, and C.M. Henderson. 2015. Environmental controls on the genesis of marine microbialites and dissolution surface associated with the end-Permian mass extinction: New sections and observations from the Nanpanjiang Basin, South China. Palaios 30: 529-552.

Li, R., and B. Jones. 2017. Diagenetic overprint on negative $\delta 13 \mathrm{C}$ excursions across the Permian/Triassic boundary: A case study from Meishan section, China. Palaeogeography, Palaeoclimatology, Palaeoecology 468: 18-33.

Liang, H. 2002. End-Permian catastrophic event of marine acidification by hydrated sulfuric acid: Mineralogical evidence from Meishan Section of South China. Chinese Science Bulletin 47: 1393-1397.

Lin, Z., X. Sun, Y. Lu, L. Xu, J. Gong, H. Lu, B.M.A. Teichert, and J. Peckmann. 2016. Stable isotope patterns of coexisting pyrite and gypsum indicating variable methane flow at a seep site of the Shenhu area, South China Sea. Journal of Asian Earth Sciences 123: 213-223.

Liu, J., Y. Ezaki, S. Yang, H. Wang, and N. Adachi. 2007. Age and sedimentology of microbialites after the end-Permian mass extinction in Luodian, Guizhou Province. Journal of Palaeogeography 9: 473-486.
Luo, G., L.R. Kump, Y. Wang, J. Tong, M.A. Arthur, H. Yang, J. Huang, H. Yin, and S. Xie. 2010. Isotopic evidence for an anomalously low oceanic sulfate concentration following endPermian mass extinction. Earth and Planetary Science Letters 300: 101-111.

Mann, S. 2002. Biomineralization: Principles and concepts in bioinorganic materials chemistry. Oxford: Oxford University Press.

McRoberts, C.A. 2010. Biochronology of Triassic bivalves. Geological Society of London, Special Publications 334: 201-219.

Mills, D.B., L.M. Ward, C. Jones, B. Sweeten, M. Forth, A.H. Treusch, and D.E. Canfield. 2014. Oxygen requirements of the earliest animals. Proceedings of the National Academy of Sciences 111: 4168-4172.

Muscente, A.D., A. Prabhu, H. Zhong, A. Eleish, M.B. Meyer, P. Fox, R.M. Hazen, and A.H. Knoll. 2018. Quantifying ecological impacts of mass extinctions with network analysis of fossil communities. Proceedings of the National Academy of Sciences 115: 5217-5222.

Payne, J.L., and M.E. Clapham. 2012. End-Permian Mass Extinction in the Oceans: An Ancient Analog for the Twenty-First Century? Annual Review of Earth and Planetary Sciences 40: 89-111.

Payne, J.L., D.J. Lehrmann, J. Wei, M.J. Orchard, D.P. Schrag, and A.H. Knoll. 2004. Large perturbations of the carbon cycle during recovery from the End-Permian extinction. Science 305: 506-509.

Payne, J.L., A.V. Turchyn, A. Paytan, D.J. DePaolo, D.J. Lehrmann, M. Yu, and J. Wei. 2010. Calcium isotope constraints on the endPermian mass extinction. Proceedings of the National Academy of Sciences 107: 8543-8548.

Pei, Y., Z.-Q. Chen, Y. Fang, S. Kershaw, S. Wu, and M. Luo. 2019. Volcanism, redox conditions, and microbialite growth linked with the end-Permian mass extinction: Evidence from the Xiajiacao section (western Hubei Province), South China. Palaeogeography, Palaeoclimatology, Palaeoecology 519: 194-208.

Penn, J.L., C. Deutsch, J.L. Payne, and E.A. Sperling. 2018. Temperature-dependent hypoxia explains biogeography and severity of end-Permian marine mass extinction. Science 362: eaat1327.

Plotnick, R.E., F.A. Smith, and S.K. Lyons. 2016. The fossil record of the sixth extinction. Ecology Letters 19: 546-553.

Posth, N.R., L.A. Bristow, R.P. Cox, K.S. Habicht, F. Danza, M. Tonolla, N.-U. Frigaard, and D.E. Canfield. 2017. Carbon isotope fractionation by anoxygenic phototrophic bacteria in euxinic Lake Cadagno. Geobiology 15: 798-816.

Preuß, A., R. Schauder, G. Fuchs, and W. Stichler. 1989. Carbon isotope fractionation by autotrophic bacteria with three different $\mathrm{CO}_{2}$ fixation pathways. Zeitschrift für Naturforschung 44: 397-402.

Raup, D.M. 1979. Size of the Permo-Triassic bottleneck and its evolutionary implications. Science 206: 217-218.

Raup, D.M., and J.J. Sepkoski. 1982. Mass extinctions in the marine fossil record. Science 215: 1501-1503.

Reitner, J. 1993. Modern cryptic microbialite/metazoan facies from Lizard Island (Great Barrier Reef, Australia) formation and concepts. Facies 29: 3-39.

Reitner, J., F. Neuweiler, and P. Gautret. 1995a. Modern and fossil automicrites: implications for mud mound genesis. In Mud mounds: A polygenetic spectrum of fine-grained carbonate buildups, eds. G. Flajs, M. Vigener, H. Keupp, D. Meischner, F. Neuweiler, J. Paul, J. Reitner, K. Warnke, H. Weller, P. Dingle, C. Hensen, P. Schäfer, P. Gautret, R.R. Leinfelder, H. Hüssner, and B. Kaufmann. Facies 32: 1-69.

Reitner, J., P. Gautret, F. Marin, and F. Neuweiler. 1995b. Automicrite in a modern marine microbialite. Formation model via organic matrices (Lizard Island, Great Barrier Reef, Australia). Bulletin de l'Institut Océanographique (Monaco) Numéro Spécial 14: 237-263. 
Reitner, J., V. Thiel, H. Zankl, W. Michaelis, G. Wörheide, and P. Gautret. 2000. Organic and biogeochemical patterns in cryptic microbialites. In Microbial sediments, eds. R.E. Riding and S.M. Awramik, 149-160. Berlin/Heidelberg: Springer.

Reitner, J., G. Wörheide, R. Lange, and S.-K. Gabriela. 2001. Coralline demosponges-a geobiological portrait. Bulletin of the Tohoku University Museum 1: 219-235.

Riding, R. 2000. Microbial carbonates: the geological record of calcified bacterial-algal mats and biofilms. Sedimentology 47 (Suppl. 1): 179-214.

Sepkoski, J.J., R.K. Bambach, D.M. Raup, and J.W. Valentine. 1981. Phanerozoic marine diversity and the fossil record. Nature 293: 435-437.

Shen, S.-Z., J. Ramezani, J. Chen, C. Cao, D.H. Erwin, H. Zhang, L. Xiang, S.D. Schoepfer, C.M. Henderson, Q.-F. Zheng, S. Bowring, Y. Wang, X.-H. Li, X.-D. Wang, D.-X. Yuan, Y.-C. Zhang, L. Mu, J. Wang, and Y.-S. Wu. 2019. A sudden end-Permian mass extinction in South China. The Geological Society of America, Bulletin 131: 205-223.

Song, H., P.B. Wignall, J. Tong, and H. Yin. 2013. Two pulses of extinction during the Permian-Triassic crisis. Nature Geoscience 6: 52-56.

Song, H., J. Tong, T.J. Algeo, H. Song, H. Qiu, Y. Zhu, L. Tian, S. Bates, T.W. Lyons, G. Luo, and L.R. Kump. 2014. Early Triassic seawater sulfate drawdown. Geochimica et Cosmochimica Acta 128: 95-113.

Stanley, S.M. 2016. Estimates of the magnitudes of major marine mass extinctions in earth history. Proceedings of the National Academy of Sciences 113: 6325-6334.

Sun, Y., M.M. Joachimski, P.B. Wignall, C. Yan, Y. Chen, H. Jiang, L. Wang, and X. Lai. 2012. Lethally hot temperatures during the Early Triassic greenhouse. Science 338: 366-370.

Sun, Y., M.J. Zulla, M.M. Joachimski, D.P.G. Bond, P.B. Wignall, Z. Zhang, and M. Zhang. 2019. Ammonium ocean following the end-Permian mass extinction. Earth and Planetary Science Letters 518: 211-222.

Tang, H., S. Kershaw, H. Liu, X. Tan, F. Li, G. Hu, C. Huang, L. Wang, C. Lian, L. Li, and X. Yang. 2017. Permian-Triassic boundary microbialites (PTBMs) in southwest China: implications for paleoenvironment reconstruction. Facies 63: 2.

Trichet, J., and C. Défarge. 1995. Non-biologically supported organomineralization. Bulletin de l'Institut Océanographique (Monaco) Numéro Spécial 14: 203-236.

Wang, Y., J. Tong, J. Wang, and X. Zhou. 2005. Calcimicrobialite after end-Permian mass extinction in South China and its palaeoenvironmental significance. China Science Bulletin 50: 665-671.

Wang, L., P.B. Wignall, Y. Wang, H. Jiang, Y. Sun, G. Li, J. Yuan, and X. Lai. 2016. Depositional conditions and revised age of the Permo-Triassic microbialites at Gaohua section, Cili Country (Hunan Province, South China). Palaeogeography, Palaeoclimatology, Palaeoecology 443: 156-166.

Wang, X., P.A. Cawood, H. Zhao, L. Zhao, S.E. Grasby, Z.-Q. Chen, P.B. Wignall, Z. Lv, and C. Han. 2018. Mercury anomalies across the end Permian mass extinction in South China from shallow and deep water depositional environments. Earth and Planetary Science Letters 496: 159-167.

Wang, T., R.V. Burne, A. Yuan, Y. Wang, and Z. Yi. 2019. The evolution of microbialite forms during the Early Triassic transgression: A case study in Chongyang of Hubei Province, South China. Palaeogeography, Palaeoclimatology, Palaeoecology 519: 209-220.

Warren, J.K. 2006. Evaporites: Sediments, resources and hydrocarbons. Berlin/Heidelberg: Springer.
Wignall, P.B. 2007. The End-Permian mass extinction-how bad did it get? Geobiology 5: 303-309.

Wignall, P.B., and M.J. Benton. 1999. Lazarus taxa and fossil abundance at times of biotic crisis. Journal of the Geological Society, London 156: 453-456.

Wignall, P.B., and A. Hallam. 1992. Anoxia as a cause of the Permian/ Triassic mass extinction: Facies evidence from Northern Italy and the Western United States. Palaeogeography, Palaeoclimatology, Palaeoecology 93: 21-46.

Wolf, K.H. 1965. Gradational sedimentary products of calcareous algae. Sedimentology 5: 1-37.

Woods, A.D. 2014. Assessing Early Triassic paleoceanographic conditions via unusual sedimentary fabrics and features. Earth-Science Reviews 137: 6-18.

Woods, A.D., D.J. Bottjer, M. Mutti, and J. Morrison. 1999. Lower Triassic large sea-floor carbonate cements: Their origin and a mechanism for the prolonged biotic recovery from the end-Permian mass extinction. Geology 27: 645-648.

Wu, Y., H. Jiang, W. Yang, and J. Fan. 2007. Microbialite of anoxic condition from Permian-Triassic transition in Guizhou, China. Science in China (Series D: Earth Sciences) 50: 1040-1051.

Wu, S., Z.-Q. Chen, Y. Fang, Y. Pei, and H. Yang. 2017. A PermianTriassic boundary microbialite deposit from the eastern Yangtze Platform (Jiangxi Province, South China): Geobiologic features, ecosystem composition, and redox conditions. Palaeogeography, Palaeoclimatology, Palaeoecology 486: 58-73.

Xie, S., R.D. Pancost, J. Huang, P.B. Wignall, J. Yu, X. Tang, L. Chen, X. Huang, and X. Lai. 2007. Changes in the global carbon cycle occurred as two episodes during the Permian-Triassic crisis. Geology 35: 1083-1086.

Yang, Z., S. Wu, H. Yin, G. Xu, and K. Zhang. 1991. Geological events during Permian and Triassic transition in South China. Beijing: Geological Publishing House.

Yang, H., Z.-Q. Chen, Y. Wang, J. Tong, H. Song, and J. Chen. 2011. Composition and structure of microbialite ecosystems following the end-Permian mass extinction in South China. Palaeogeography, Palaeoclimatology, Palaeoecology 308: 111-128.

Yang, H., Z.-Q. Chen, K. Stephen, W. Liao, E. Lü, and Y. Huang. 2019. Small microbialites from the basal Triassic mudstone (Tieshikou, Jiangxi, South China): Geobiologic features, biogenicity, and paleoenvironmental implications. Palaeogeography, Palaeoclimatology, Palaeoecology 519: 221-235.

Yin, H., K. Zhang, J. Tong, Z. Yang, and S. Wu. 2001. The Global Stratotype Section and Point (GSSP) of the Permian-Triassic Boundary. Episodes 24: 102-114.

Yin, H., S. Xie, G. Luo, T.J. Algeo, and K. Zhang. 2012. Two episodes of environmental change at the Permian-Triassic boundary of the GSSP section Meishan. Earth-Science Reviews 115: 163-172.

Zhang, F., T.J. Algeo, S.J. Romaniello, Y. Cui, L. Zhao, Z.-Q. Chen, and A.D. Anbar. 2018. Congruent Permian-Triassic $\delta^{238} U$ records at Panthalassic and Tethyan sites: Confirmation of global-oceanic anoxia and validation of the U-isotope paleoredox proxy. Geology 46: 327-330.

Zhao, X., J. Tong, H. Yao, K. Zhang, and Z.-Q. Chen. 2008. Anachronistic facies in the Lower Triassic of South China and their implications to the ecosystems during the recovery time. Science in China Series D: Earth Sciences 51: 1646-1657.

Zhao, L., Y. Chen, Z.-Q. Chen, and L. Gao. 2013. Uppermost Permian to Lower Triassic conodont zonation from three gorges area, South China. Palaios 28: 523-540. 